\section{O PROCESSO DE ELABORAÇÃO DA BASE NACIONAL COMUM CURRICULAR (BNCC) NO BRASIL E A SOCIOLOGIA (2014 a 2018)}

\author{
THE COMMON NATIONAL CURRICULAR BASE PROCESS OF ELABORATION IN BRAZIL AND SOCIOLOGY
}

\author{
Ileizi Fiorelli Silva ${ }^{1}$ \\ Henrique Fernandes Alves Neto ${ }^{2}$
}

\begin{abstract}
Resumo: $O$ presente estudo tem como objetivo analisar o processo de elaboração da Base Nacional Comum Curricular (BNCC) entre 2014 e 2018 no Brasil. As questões da investigação são as seguintes: quais modelos de currículos e propostas educacionais foram postas em disputas no contexto em que os agentes responsáveis formularam os documentos oficiais? Como a sociologia foi tratada em cada proposta elaborada? Como os diferentes princípios organizadores das propostas foram alterados, ressignificados ou rearticula dos nos diferentes textos dos documentos? Quais princípios e formas de organização da BNCC predominaram na proposta vencedora ao longo desse processo? Como a sociologia é integrada na proposta final? Desde as perspectivas de Basil Bernstein nos estudos sobre currículos, analisamos quatro documentos e suas propostas em três contextos políticos: a) a fase de consolidação da ideia de Educação Básica abrangente, da Educação Infantil ao Ensino Médio e dos direitos à aprendizagem (2012 a 2014); b) a fase da conciliação entre as perspectivas dos direitos da aprendizagem e das matrizes de conteúdos elaboradas no sistema de avaliação em larga escala (2015 e 2016) e posterior rompimento do debate nacional junto da reforma do Ensino Médio (2016 a 2017); c) a fase de finalização da BNCC, especialmente a parte do Ensino Médio (2017-2018). Demonstramos também o quadro das quatro propostas de BNCC e a situação da Sociologia nos respectivos documentos $(2014 ; 2015 ; 2016 ; 2018)$. A análise indicou que a Sociologia presente nas quatro propostas foi capturada pelo discurso pedagógico hegemônico e predominante em cada debate. $O$ discurso pedagógico ainda está codificado pelos persistentes embates dos princípios que organizam os currículos em torno dos componentes curriculares (disciplinas) ou do modelo das competências e habilidades.
\end{abstract}

Palavras-Chaves: base nacional comum curricular; políticas curriculares; sociologia.

\begin{abstract}
The present study aims to analyze the process of elaboration of the Common National Curricular Base (BNCC) in Brazil between 2014 and 2018. The research questions were as follows: what curriculum models and educational proposals were in dispute in the context they were formulated? How was sociology approached in each proposal? How were the different organizing principles modified, re-signified or rearticulated in the different texts of the documents? Which BNCC principles and forms of organization prevailed in the winning proposal throughout the process? How was sociology integrated into the final proposal? Based on Basil Bernstein's perspectives on curriculum studies, we have analyzed four documents and their proposals in three different political contexts: a) the consolidation phase of the idea of Basic Education, from Pre-school to High School, and of the learning rights (2012 to 2014); b) the conciliation phase between learning rights and content matrices perspectives of large-scale assessments (2015 and 2016); c) the disruption phase of the national debate and the High School reform (2016 to 2018). The study includes a table containing the four BNCC proposals as well as the situation of Sociology in those documents $(2014 ; 2015 ; 2016 ; 2018)$. The analysis showed that the sociology found in the four proposals was captured by the predominant hegemonic pedagogical discourse in each debate. Pedagogical discourse is still encoded by persistent clashes over the curricula organizing principles, its components (subjects) or in the competencies and skills model.
\end{abstract}

1Doutora em Sociologia pela Universidade de São Paulo (USP), Professora da Universidade Estadual de Londrina (UEL) e do Programa de Pós-Graduação de Sociologia; Coordenadora do Mestrado Profissional de Sociologia e da Especialização em Ensino de Sociologia. E-mail: ileizisilva@hotmail.com. Orcid: https://orcid.org/0000-0002-87449120

2 Mestre em Ciências Sociais pela Universidade Estadual de Londrina (UEL), Professor do Instituto Federal do Paraná (IFPR). E-mail: henriqueaneto@hotmail.com. Orcid: https://orcid.org/0000-0002-0371-0302 
Key words: common national curricular base; curricular policies; sociology.

Resumen: El presente estudio tiene como objetivo analizar el proceso de elaboración de la Base Nacional Común Curricular (BNCC) entre 2014 y 2018 en Brasil. Las preguntas de investigación son las siguientes: ¿qué modelos de currículo y propuestas educativas se pusieron en disputa en el contexto en el que los agentes responsables formularon los documentos oficiales? ¿Cómo se trató la sociología en cada propuesta? ¿Cómo se cambiaron, resignificaron o re-articularon los diferentes principios de organización de las propuestas en los diferentes textos de los documentos? ¿Qué principios y formas de organización del BNCC predominaron en la propuesta ganadora durante todo este proceso? ¿Cómo se integra la sociología en la propuesta final? Desde la perspectiva de Basil Bernstein en los estudios curriculares, analizamos cuatro documentos y sus propuestas en tres contextos políticos: a) la fase de consolidación de la idea de Educación Básica integral, desde la Educación Infantil hasta la Educación Secundaria y los derechos al aprendizaje (2012 a 2014 ); b) la fase de reconciliación entre las perspectivas de los derechos de aprendizaje y las matrices de contenido elaboradas en el sistema de evaluación a gran escala (2015 y 2016) y la posterior ruptura del debate nacional con la reforma de la Educación Secundaria (2016 a 2017); c) la fase de finalización de BNCC, especialmente la parte de la Educación Secundario (2017-2018). También mostramos la tabla de las cuatro propuestas de BNCC y la situación de la sociología en los documentos respectivos (2014; 2015; 2016; 2018). El análisis indicó que la sociología presente en las cuatro propuestas fue capturada por el discurso pedagógico hegemónico y predominante en cada debate. El discurso pedagógico todavía está codificado por los enfrentamientos persistentes entre los principios que organizan los planes de estudio en torno a los componentes curriculares (asignaturas) o el modelo de competencias y habilidades.

Palabras clave: base nacional común curricular; políticas curriculares; sociología.

\section{INTRODUÇÃO}

Este artigo continua as reflexões iniciadas no texto publicado em 2015 (SILVA et all, 2015), em que analisamos duas propostas de BNCC, uma publicada em 2014 e outra em 2015. Agora, neste novo texto, nos propomos a analisar as quatro propostas de BNCC desde 2014 até a publicada em 2018, vencedora no processo de disputas que dependeram de contextos políticos muito distintos, que dividimos em três fases.

Apresentaremos, então, algumas reflexões sobre o processo de elaboração da Base Nacional Comum Curricular - BNCC no Brasil e a relação com Sociologia, no período de 2014 a 2018, quando o Ministério da Educação desencadeou ações concretas e planejadas para a construção de uma base nacional comum curricular para todos os entes federados, ou seja, estados e municípios, e para todas as etapas da Educação Básica, da Educação Infantil ao Ensino Médio. Foi uma ação decorrente da necessidade de cumprir as legislações vigentes, tais como a Constituição Federal de 1988, a Lei de Diretrizes e Bases da Educação Nacional (LDBEN) de 1996 e o Plano Nacional de Educação (PNE) de 2014. Além disso, houve uma mobilização do "Movimento Todos pela Educação" e do "Movimento pela Base", iniciativa de setores sociais da sociedade civil, especialmente, das fundações ligadas ao setor financeiro, de empresas privadas e empresários, além de educadores e outras organizações não governamentais. Algumas associações de pesquisas e pesquisadores do campo da educação, tais como Associação Nacional de Pesquisa e Pós-graduação da Educação (ANPED), posicionaram-se contrárias à elaboração de uma Base Nacional Comum e/ou ao método de elaboração desde a formação das primeiras equipes de especialistas em 2013 e 2014 (SILVA et all, 2015; MICHETTI, 2020).

A despeito dos acirrados debates e da instabilidade política do Brasil, desde as primeiras movimentações pelo golpe jurídico e midiático que culminou no impeachment da presidenta Dilma Rousseff, em 2016, os trabalhos de feitura da BNCC foram concluídos em dezembro de 2018. Entretanto, esse curto período foi marcado por três fases distintas, a saber: a) a fase de consolidação da ideia de Educação Básica abrangente, da Educação Infantil ao Ensino Médio e dos direitos da aprendizagem (2012 a 2014); b) a fase da conciliação entre as perspectivas dos direitos da aprendizagem e das matrizes de conteúdos elaboradas no sistema de avaliação em larga escala (2015 e 2016) e posterior rompimento do debate nacional junto da reforma do Ensino Médio (2016 a 2017); c) a fase de finalização da BNCC, especialmente a parte do Ensino Médio (2017-2018). Apresentaremos o quadro das quatro propostas e a situação da Sociologia nesses documentos.

\section{OS TERMOS E A METODOLOGIA DA ANÁLISE}

Basil Bernstein possui um conjunto de conceitos que nos auxiliam na solução do problema 
sociológico posto. São eles: código (restrito e elaborado), classificação, enquadramento, pedagogia visível e pedagogia invisível, discurso vertical e discurso horizontal e a sua teoria do dispositivo pedagógico. É necessário fazer uma breve descrição de cada um desses conceitos, pois eles são importantes para a compreensão dos procedimentos de pesquisa descritos abaixo. Além de alguns textos de Bernstein (1971, 1975, 1996 e 1998), mobilizamos os artigos de Mainardes e Stremel (2010) e Morais e Neves (2007) como base dessas descrições.

Bernstein entende código como um princípio regulador que é adquirido tacitamente que seleciona e integra significados relevantes, determina a forma de realização e evoca os contextos nos quais ele é possível (BERNSTEIN, 1996). Estes códigos, por sua vez, podem ser separados em dois tipos: restritos, sendo aqueles que estão muito vinculados a um contexto específico, portanto, com significados particulares; e os elaborados, sendo estes universalistas e não dependentes de um contexto. Morais e Neves (2007) exemplificam esses códigos em dois ambientes sociais distintos: o primeiro localizado na família - e estas podem ter códigos restritos e elaborados, a depender da classe social e outras instituições sociais que a família ocupa; e o segundo presente na escola.

Os códigos, como princípios reguladores, determinam o grau de classificação e enquadramento das realizações a serem feitas a partir deles. Classificação, para Bernstein, e sintetizado por Mainardes e Stremel (2010) "é usado para descrever as relações de poder e controle do que é ensinado e aprendido" (p. 8), enquanto que Enquadramento, também resumido pelos autores, "é usado para descrever as relações de poder e controle que influenciam o como o processo ensino/aprendizagem é conduzido" (p. 8). Assim, a classificação pode ser forte ou fraca, bem como o enquadramento pode ser forte ou fraco. $O$ que irá determinar o nível de força são critérios como: limites estabelecidos entre disciplinas, compassamento, papéis sociais, sequenciamento, forma, e assim por diante. Quanto mais rígidos e delimitados estes critérios, a classificação e o enquadramento ganham o adjetivo forte, e vice-versa, quanto mais flexível e nebuloso o critério, o adjetivo de fraco.

Este conjunto de relações, entre códigos, classificação e enquadramento é que possibilita Bernstein (1996) a estabelecer a diferença entre dois tipos de pedagogia: visível e invisível. Partindo das ideias acima apresentadas, uma pedagogia visível é aquela com uma classificação e enquadramentos fortes, possivelmente, com um código elaborado; a pedagogia invisível, por sua vez, é caracterizada por uma classificação e um enquadramentos fracos. O discurso utilizado nessas pedagogias pode ser do tipo vertical (coerente, explícita e com princípios sistematizados) ou do tipo horizontal (segmentado, dependente de contexto) (MAINARDES; STREMEL, 2010).

Por fim, tratando de Bernstein, temos a teoria do dispositivo pedagógico. Criado para analisar como uma disciplina ou área do conhecimento, é determinada para compor o conhecimento escolar, o dispositivo pedagógico pode ser entendido através da metáfora de uma gramática. Com regras, ordens, posições e categorias, o dispositivo pedagógico dá forma ao chamado discurso pedagógico:

[...] um discurso sem um discurso específico. Ele não tem qualquer discurso próprio. $O$ discurso pedagógico é um princípio para apoiar outros discursos e colocá-los numa relação mútua especial, com vistas à sua transmissão e aquisição seletivas. O discurso pedagógico é, pois, um princípio que tira (desloca) um discurso de sua prática e contexto substantivos e reloca aquele discurso de acordo com seu próprio princípio de focalização e reordenamento seletivos. Nesse processo de deslocação e relocação, o discurso original passa por uma transformação: de uma prática real para uma prática virtual ou imaginária. (BERNSTEIN, 1996, p. 259)

Por sua vez, este discurso pedagógico é recontextualizado dependendo do espaço social no qual ele é pronunciado. Esse processo de recontextualização acontece em quatro contextos distintos: a) agências contextualizadoras (universidades e centros de pesquisa); b) agências recontextualizadoras oficiais (Ministério da Educação, Secretaria de Educação); c) agências recontextualizadoras não-oficiais (meios de comunicação de massa, família, igreja); d) agências recontextualizadoras pedagógicas (sala de aula) (CORREIA LIMA, 2012; p. 28). Bernstein, com sua proposta teórica, procura elucidar os caminhos que um discurso trilha até chegar em sua realização mais elementar: a sala de aula. Ele nos chama atenção 
nas possíveis ressignificações que certo discurso pode tomar até alcançar o ponto final de um determinado processo (ver figura 1).

Figura 1 - Discurso pedagógico

\section{Discurso pedagógico}

\section{Discurso pedagógico oficial}

Código

Restrito

Classificação

Enquadramento Classificação

Enquadramento

\section{Código Elaborado}

Classificação

\section{Campo}

Contextualizador Oficial

\author{
Classificaçào
}

Enquadramento

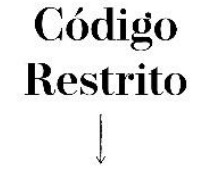

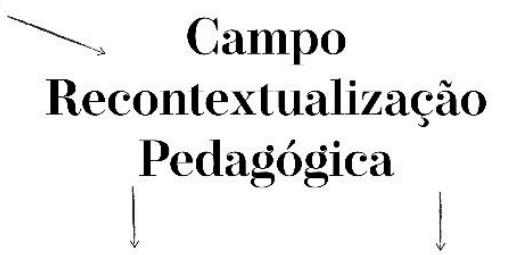

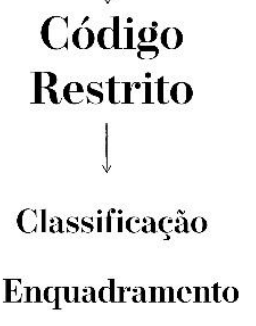

\section{Código} Elaborado

Classificaçào

Encuadramento

Fonte: Elaborada Pelos autores

A análise dos quatro documentos que pretendiam tornar-se a BNCC identificou que os agentes e as agências operavam com a noção de competências para informar os dispositivos pedagógicos e para a estruturação do discurso pedagógico. Nossa hipótese é a de que essa noção foi ressignificada de várias maneiras nas quatro propostas que analisamos no âmbito do discurso pedagógico oficial no campo de recontextualização pedagógica apenas nas instâncias de Governo, não chegando à sala de aula. É o que discutiremos na sequência.

\section{A BNCC É CURRÍCULO? COMO ENTENDER A PRESENÇA DA SOCIOLOGIA NAS PROPOSTAS?}

No debate técnico sobre a função da BNCC aparece a pergunta se ela seria currículo ou funcionaria como orientações, parâmetros e diretrizes. Para nossa análise teórica essa dúvida não faz sentido, porque currículo é algo mais amplo, que envolve desde as práticas diárias de aulas ministradas em todas as escolas, em que as professoras escolhem conteúdos, métodos, atividades e, portanto, produzem currículo, o currículo real, até as legislações municipais, estaduais e nacionais que informam às professoras o que elas deveriam ensinar. Assim, em termos analíticos, a BNCC é currículo, pois mobiliza agentes e agências em torno de si, tem significado e significância para o campo da educação e para os diferentes campos da ciência. Adquiriu importância para vários setores da sociedade civil, movimentos sociais, partidos políticos, grupos religiosos e igrejas, enfim, tornou-se, claramente, um campo de disputas e lutas acirradas. Para a sociologia da educação (BERNSTEIN, 1996; 2000) isso é currículo, um terreno complexo e dinâmico nas sociedades modernas (SILVA, 2005).

Entretanto, o debate técnico de definição política do que será a BNCC na arquitetura do sistema de ensino brasileiro é importante. Se ela tornar-se uma grade fechada de componentes curriculares e de conteúdos predefinidos para todos os estados e municípios do Brasil, daí ela se constituirá em currículo centralizado e centralizador, como foi, por exemplo, no período da Ditatura Militar (1964-1985), pois todas as escolas ensinavam desde a mesma grade curricular. Se ela se tornar uma base comum de um conjunto de conhecimentos, habilidades, competências, componentes curriculares como ponto de partida para as escolas, municípios e estados elaborarem suas propostas de conteúdos, habilidades, competências, componentes curriculares, temas, problemas que articulem essa "base comum" com as regiões e suas especificidades, daí ela não será grade curricular ou currículo nesse sentido stricto, mas será mesmo parâmetro e orientação.

Certamente, para entendermos a Sociologia nesse processo e nas quatro propostas deveremos entender os princípios de ordenamento do discurso pedagógico, que por meio de dispositivos discursivos 
e da gramática que define os códigos e as classes de enquadramento dos textos, indicará o lugar e o papel dos componentes curriculares, ou das disciplinas, como costumamos chamar as áreas de conhecimentos que se tornam disciplinas escolares. A Sociologia, assim como as demais disciplinas, estará condicionada por esses princípios de ordenamento da produção, recontextualização e reprodução na estruturação do discurso pedagógico (SILVA, 2007).

Fica demonstrado que a situação da Sociologia dentro dos currículos da Educação Básica depende de todos os processos que são desencadeados no sentido da estruturação do discurso pedagógico desde as instâncias do Estado até chegar na sala de aula. Como estamos estudando uma proposta governamental, analisaremos a Sociologia apenas nessa camada e nessa instância que participa e define parte do discurso pedagógico que ordenará o sistema de ensino por algum tempo (BERNSTEIN, 2000). Assim a legislação brasileira desde a Constituição Federal de 1988, a LDBEN de 1996, as diretrizes nacionais de cada nível de ensino, o PNE aprovado em 2014 e várias outras normas compõem os sentidos da educação nacional e situam o papel de cada campo de conhecimento dentro desse aparato. Compõem, assim, o campo da recontextualização pedagógica oficial (BERNSTEIN, 1996, p. 270). A BNCC como ação política e de política pública tornou-se mais uma ação no campo de recontextualização pedagógica oficial de ordenamento dos processos de ensino e aprendizagem nas escolas, e, portanto, do discurso pedagógico

\section{A BNCC EM TRÊS TEMPOS E AS QUATRO PROPOSTAS}

É possível demonstrar como os agentes dos campos da produção e do controle simbólico agiram fortemente para disputar no campo de recontextualização pedagógica oficial. Nos três momentos e nos quatro documentos formulados, agentes e agências de diversos setores e subcampos da economia e do controle simbólico inseriram-se no Ministério de Educação (MEC), no Conselho Nacional de Secretários de Educação (CONSED), na União dos Dirigentes Municipais de Educação (UNDIME), no Conselho Nacional de Educação e nos grupos formados para debater e definir a BNCC.

O primeiro momento desse processo de construção da BNCC chamamos de fase de consolidação da ideia de Educação Básica abrangente, da Educação Infantil ao Ensino Médio e de direitos à aprendizagem e ao desenvolvimento (2012 a 2014).

Desde 2011, formou-se um grupo no MEC denominado de Grupo de Trabalho (GT) dos Direitos à Aprendizagem, liderado pela Diretoria de Políticas de Currículos, que formulou uma proposta para a discussão da Base Nacional Comum. Seguindo a metodologia de trabalho estabilizada no MEC, o grupo finalizou o documento de 2014, intitulado "Por uma política curricular para a educação básica: contribuição ao debate da base nacional comum a partir do direito à aprendizagem e ao desenvolvimento. Versão Preliminar". O grupo de setenta e quatro agentes, sendo a maioria de Instituições de Ensino Superior (SILVA et all, 2015), traduziu a legislação produzida desde 1988, reforçando a Educação Básica como direito universal, indo da Educação Infantil ao Ensino Médio, sendo este a última etapa da formação. Se a Educação Básica é um direito dos cidadãos e um dever do Estado, os conhecimentos a serem ensinados e aprendidos são entendidos como direitos, direitos à aprendizagem e ao desenvolvimento. As áreas e os componentes curriculares foram pensados dentro de um longo processo de garantia dos direitos à aprendizagem e, por isso, foram submetidos aos quatorze direitos à aprendizagem (Ver Figura 1e Quadro 1), que foram traduzidos nos conhecimentos de cada área. Não houve um esforço para definir conhecimentos específicos de cada componente curricular de forma geral ou por séries, ou etapas. $\mathrm{O}$ percurso e detalhes de progressões seriam definidos pelos estados, municípios e escolas. 
Figura 1 - Os quatorze direitos à Aprendizagem

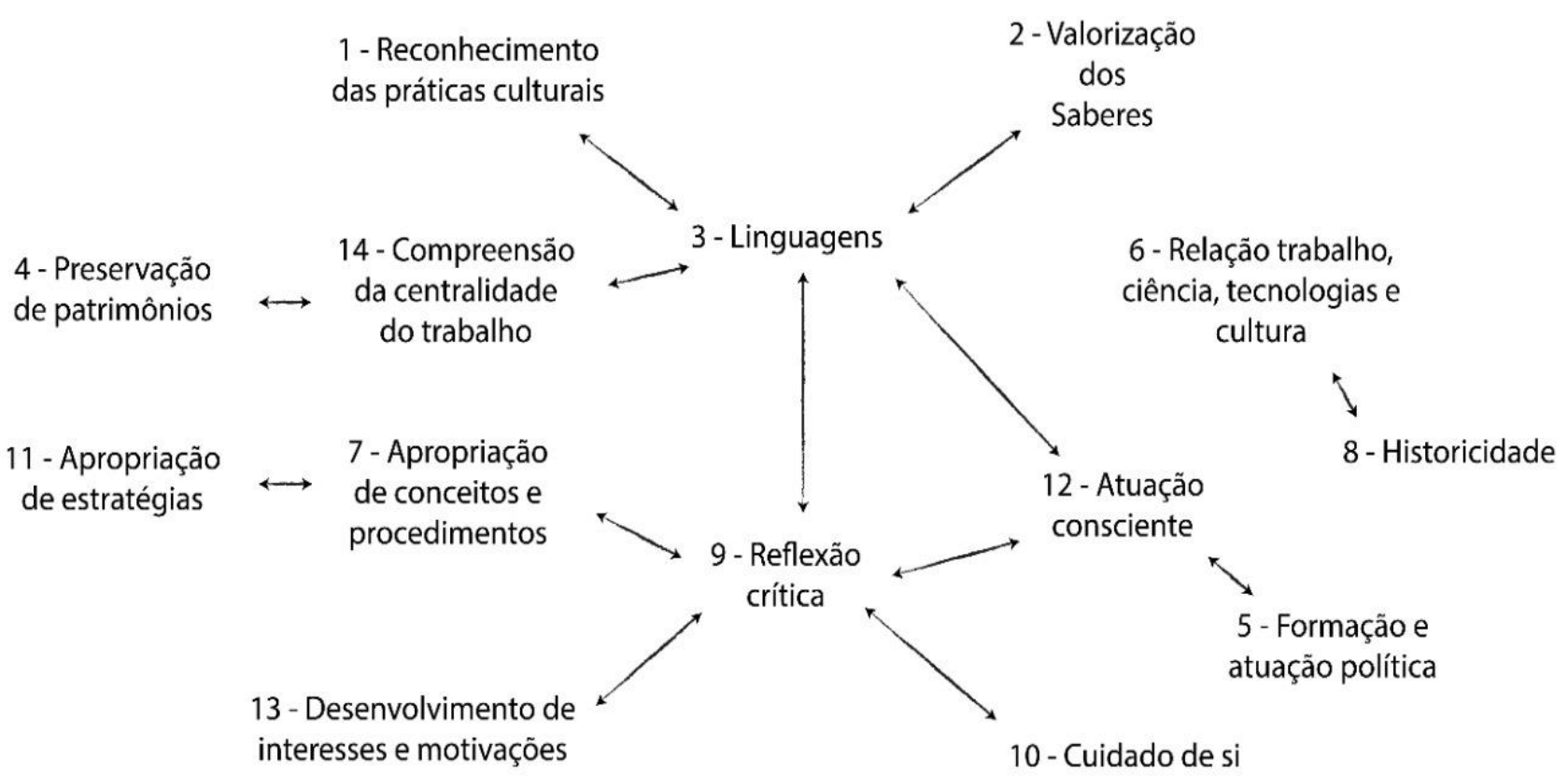

Fonte: Adaptado do documento (BRASIL, 2014, p.51).

Quadro 1 - Os Quatorze Direitos à Aprendizagem e Desenvolvimento

\begin{tabular}{|c|c|}
\hline $\begin{array}{c}\text { Direitos à } \\
\text { aprendizagem }\end{array}$ & Descrição \\
\hline $\begin{array}{l}\text { 1. Reconhecimento das } \\
\text { práticas cultuais }\end{array}$ & $\begin{array}{l}\text { Ao reconhecimento da pluralidade das práticas culturais próprios dos grupos, de forma } \\
\text { a proporcionar o diálogo entre estas e as práticas culturais próprias da escola, bem } \\
\text { como com a diversidade de valores, crenças e atitudes compatíveis com princípios } \\
\text { democráticos que favoreçam a ampliação de sua visão e leitura de mundo. }\end{array}$ \\
\hline $\begin{array}{l}\text { 2. Valorização dos } \\
\text { saberes }\end{array}$ & $\begin{array}{l}\text { Ao reconhecimento e à valorização de seus conhecimentos, saberes e diferentes formas } \\
\text { de representação e expressão, proporcionando um permanente diálogo entre estes e a } \\
\text { experiências escolar, de forma a ampliá-los e ressignificá-los. }\end{array}$ \\
\hline 3. Linguagens & $\begin{array}{l}\text { À compreensão, apropriação e ao uso de várias formas de linguagem, favorecedoras de } \\
\text { diferentes práticas sociais, expressões estéticas, científicas, tecnológicas, culturais e } \\
\text { políticas, pelo domínio de seus códigos e de sua significação social. }\end{array}$ \\
\hline $\begin{array}{l}\text { 4. Preservação de } \\
\text { patrimônios }\end{array}$ & $\begin{array}{l}\text { Ao conhecimento, à apreciação, à valorização, à fruição e à preservação de patrimônios } \\
\text { socioculturais e naturais, locais, nacionais e mundiais. }\end{array}$ \\
\hline $\begin{array}{l}\text { 5. Formação e atuação } \\
\text { política }\end{array}$ & $\begin{array}{l}\text { À compreensão da complexidade das relações de poder e das instituições políticas da } \\
\text { sociedade contemporânea, em suas dimensões simbólicas, materiais e em seus } \\
\text { aspectos normativos, bem como a participação em processos de interlocução, } \\
\text { discussão, debate, controvérsias e conflitos, para que os estudantes possam realizar } \\
\text { sua formação e atuação política. }\end{array}$ \\
\hline $\begin{array}{l}\text { 6. Relação trabalho, } \\
\text { ciência, tecnologia e } \\
\text { cultura }\end{array}$ & $\begin{array}{l}\text { Ao acesso a formas de conhecimento, saberes e experiências que permitam a } \\
\text { compreensão das relações entre trabalho, ciência, tecnologia, cultura, artes, sociedade } \\
\text { e ambiente, num processo dialógico capaz de oferecer outras possibilidades de } \\
\text { compreensão, de estratégias de solução de problemas e de intervenção na realidade. }\end{array}$ \\
\hline $\begin{array}{l}\text { 7. Apropriação de } \\
\text { conceitos e } \\
\text { procedimentos }\end{array}$ & $\begin{array}{l}\text { À apropriação de conceitos e procedimentos de diferentes tradições do conhecimento } \\
\text { humano que permitem operar com os dados da realidade, de modo a produzir } \\
\text { significados e relações que ampliem a compreensão de mundo e a possibilidade de } \\
\text { intervenção em diferentes contextos. }\end{array}$ \\
\hline 8. Historicidade & $\begin{array}{l}\text { À compreensão da historicidade como forma de desnaturalização das condições de } \\
\text { produção, de validação dos conhecimentos - materializados em suas expressões } \\
\text { culturais, estéticas, políticas, científicas, tecnológicas e religiosas - e de possibilidades } \\
\text { de interpretação e produção de sentido. }\end{array}$ \\
\hline 9. Reflexão crítica & $\begin{array}{l}\text { Ao exercício da reflexão crítica, entendida como o pensar sobre si em relação ao outro } \\
\text { e acerca das identidades, crenças, atitudes e valores socialmente compartilhados, } \\
\text { frente aos dilemas éticos da contemporaneidade. }\end{array}$ \\
\hline
\end{tabular}


ISSN $1983-1579$

Doi: 10.22478/ufpb.1983-1579.2020v13n1.51545

http://periodicos.ufpb.br/ojs2/index.php

\begin{tabular}{|c|l|}
\hline 10. Cuidado de si & $\begin{array}{l}\text { Às experiências e conhecimentos que possibilitem o desenvolvimento de práticas } \\
\text { reflexivas orientadas ao cuidado de si, como resultado do compromisso com o outro, } \\
\text { com o ambiente e com os demais territórios que compartilham. }\end{array}$ \\
\hline $\begin{array}{c}\text { 11. Apropriação de } \\
\text { estratégias }\end{array}$ & $\begin{array}{l}\text { A vivenciar diferentes estratégias de solução de problemas através da testagem de } \\
\text { hipóteses, da validação de soluções, do trabalho de campo, num processo que envolve } \\
\text { imaginação, investigação, criatividade, análise reflexiva, troca de ideias e } \\
\text { argumentações, para compreenderem-se como sujeitos que atuam na produção e na } \\
\text { transformação do conhecimento e da realidade. }\end{array}$ \\
\hline 12. Atuação consciente & $\begin{array}{l}\text { Aos conhecimentos e experiências que lhes permitam compreender e atuar frente às } \\
\text { grandes questões que afetam a vida e a dignidade humanas, pela compreensão das } \\
\text { questões socioambientais - sejam locais, ou regionais ou planetárias - da interface entre } \\
\text { natureza, sociedade e cultura e da produção e consumo, numa perspectiva crítica. }\end{array}$ \\
\hline $\begin{array}{c}\text { 13. Desenvolvimento de } \\
\text { interesses e motivações }\end{array}$ & $\begin{array}{l}\text { Ao vivenciar, no espaço escolar, experiências intencionalmente organizadas para } \\
\text { atender a interesses e necessidades específicas, ampliando o convívio com diferentes } \\
\text { grupos da comunidade escolar. }\end{array}$ \\
\hline $\begin{array}{c}\text { 14. Compreensão da } \\
\text { centralidade do } \\
\text { trabalho }\end{array}$ & $\begin{array}{l}\text { Avivenciar experiências educativas que evidenciem a centralidade do trabalho humano } \\
\text { na construção das relações sociais e na forma como os recursos e conhecimentos são } \\
\text { apropriados e distribuídos. }\end{array}$ \\
\hline
\end{tabular}

Fonte: Adaptado pelos autores desde o do documento (BRASIL, 2014, p.51).

Entre 2012 e 2014 ocorreu o Pacto pelo ensino Médio, estudos e encontros dos professores do ensino Médio em todo território nacional. Deste encontro, saiu um material produzido por vários estudiosos e especialistas das diversas áreas de conhecimento e que também debatiam o que poderia se tornar uma Base Nacional Comum Curricular. Outros programas mobilizavam os docentes das diversas etapas, níveis e modalidades de ensino no mesmo sentido, criar bases comuns para os direitos à aprendizagem da Educação Básica no Brasil ${ }^{3}$. Esse documento não chegou a ser amplamente debatido.

O segundo momento desse processo chamamos de fase da conciliação entre as perspectivas dos direitos à aprendizagem e das matrizes de conteúdos elaboradas no sistema de avaliação em larga escala (2015 e 2016). O processo anterior foi interrompido pela mudança de governo, embora a presidenta da República (2011-2014) tenha sido reeleita, Dilma Rousseff (afastada em 2016), no seu segundo mandato, mudou os gestores do MEC. Nos primeiros meses desse segundo mandato, seu ministro da educação, Cid Gomes, organizou a primeira equipe que elaboraria uma nova proposta de BNCC.

Conforme Silva et all (2015) já apontaram em outro artigo, a proposta de 2015 articulou os direitos à aprendizagem com os objetivos de aprendizagem, formatando-os de modo parecido às Matrizes de Referências do Exame Nacional do Ensino Médio (ENEM) e do Sistema de Avaliação da Educação Básica (SAEB). Certamente, isso se explica pela mudança dos agentes e agências nos direcionamentos desse trabalho. O Secretário da Educação Básica no MEC, Manuel Palácios da Cunha e Melo, é oriundo da UFJF e do CAED - Centro de Políticas Públicas e Avaliação da Educação da UFJF. A coordenadora geral do trabalho ficou a cargo de Hilda Aparecida Linhares da Silva Micarello, da UFJF, e de Isabel Cristina Alves da Silva Frade, da UFMG. ${ }^{4}$

Note-se que mantiveram as áreas de conhecimentos com seus respectivos componentes curriculares (ver Figura 2). Indicavam-se temas integradores e eixos estruturantes, mas propunham objetivos de aprendizagem (conteúdos) para cada etapa e série desde a Educação Infantil até o Ensino Médio. O componente de História não aparece nessa versão de 2015 em função das tensões e dos debates acirrados diante da decisão da equipe de especialistas em manter os conteúdos e objetivos de aprendizagem dentro das teorias decoloniais, enfatizando os estudos sobre África, Ameríndios, América Latina e tirando o foco do eurocentrismo. Até a data que o cronograma mandava publicar o documento

3 Plano de Desenvolvimento da Educação (PDE); Pacto Nacional pela Alfabetização na idade Certa (PNAIC); Programa Nacional de Integração da Educação Profissional com a Educação Básica na Modalidade de Educação de Jovens e Adultos (PROEJA); Pacto Nacional pelo Fortalecimento do Ensino Médio.

4 Para mais detalhes das equipes elaboradoras dos documentos de 2014 e 2015-2016, consultar SILVA et all (2015).

Rev. Espaço do Currículo (online), João Pessoa, v.13, n.2, p. 262-284, maio/agos. 2020. 
para consulta on line, a equipe de História não tinha, ainda, conseguido modificar ou amenizar essa orientação teórica.

Figura 2 - A Proposta de BNCC de 2015 (BRASIL, 2015)

\section{Educação Básica \\ Direito à educação}

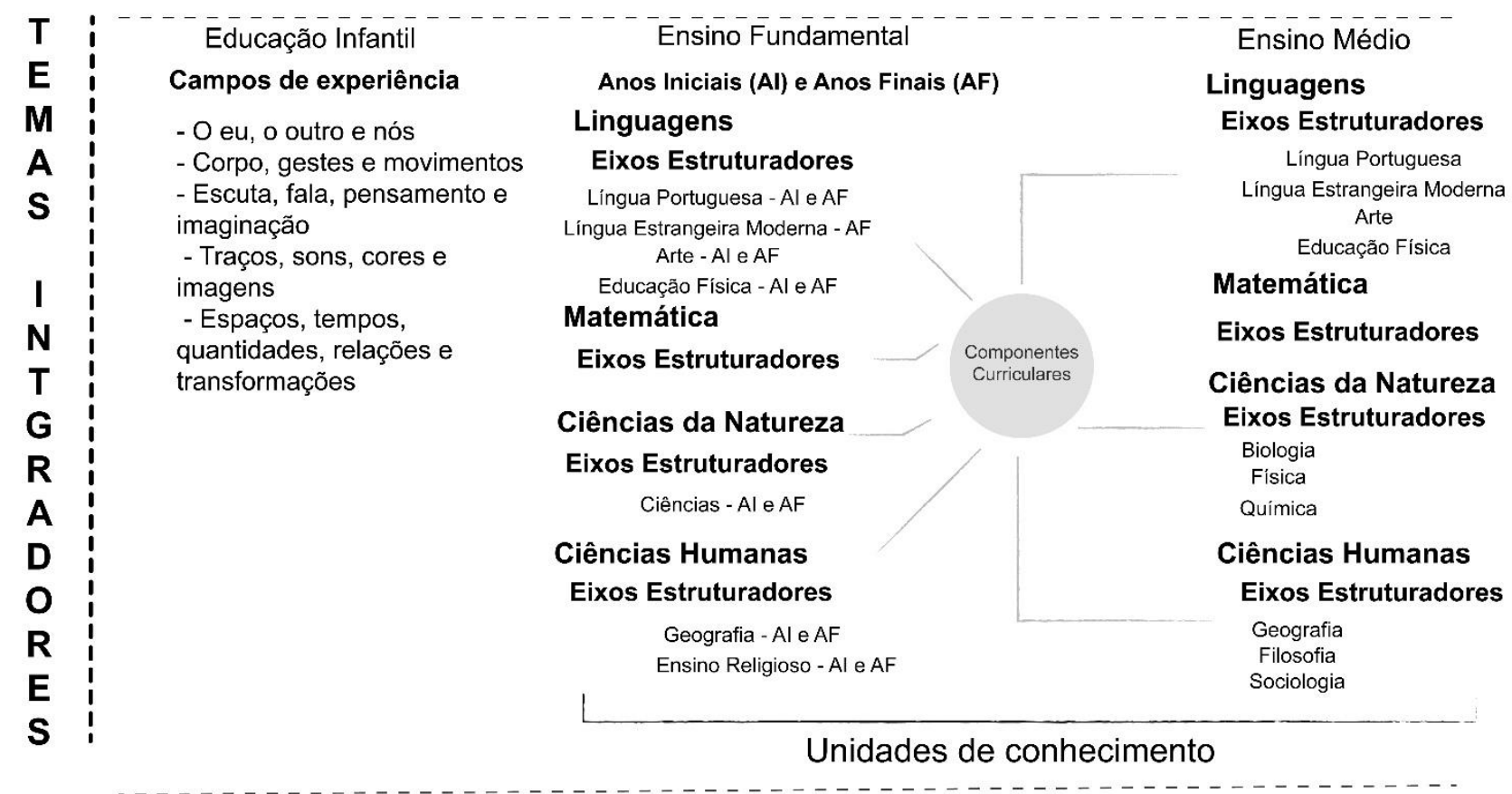

objetivos de aprendizagem

Fonte: Elaboração dos autores.

É preciso ressaltar que a Fundação Lemann, por meio do Conselho Nacional de Secretários da Educação (CONSED) e do MEC, participou ativamente dos trabalhos, trazendo assessores da Austrália e Chile para dar palestras e avaliar os trabalhos da equipe de especialistas. Os observadores do Movimento Todos pela Educação e Movimento pela Base acompanharam e registraram todas as etapas da elaboração das versões de 2015 e 2016. As tensões das equipes de especialistas com as orientações desses movimentos, das críticas das associações de pesquisa e pós-graduação, como da Associação de Pósgraduação de História (ANPUH), da Associação Nacional de Pós-Graduação e Pesquisa (ANPEd) e assim, também, por outras áreas, muitas delas expostas em jornais impressos e de televisões, pressionavam as equipes. $O$ comitê de quatorze assessores tinha trabalho intenso para mediar, articular e encontrar caminhos de consensos (BURGOS, 2017; AZEVEDO, 2018).

Essa versão da proposta, publicada em 2015, foi submetida a consulta e envio de críticas e sugestões por meio de uma plataforma online criada para esse fim. As escolas mobilizaram-se para que docentes, discentes e comunidade escolar pudessem participar. Após essa coleta de sugestões, a equipe de especialistas trabalhou nos meses de janeiro a março de 2016 para incorporar essas críticas, bem como as dos leitores críticos contratados para análise mais aprofundada. Em abril de 2016, concluíram os trabalhos da segunda versão dessa fase de elaboração da BNCC. 
Figura 3 - A Proposta de BNCC de 2016 (BRASIL, 2016).

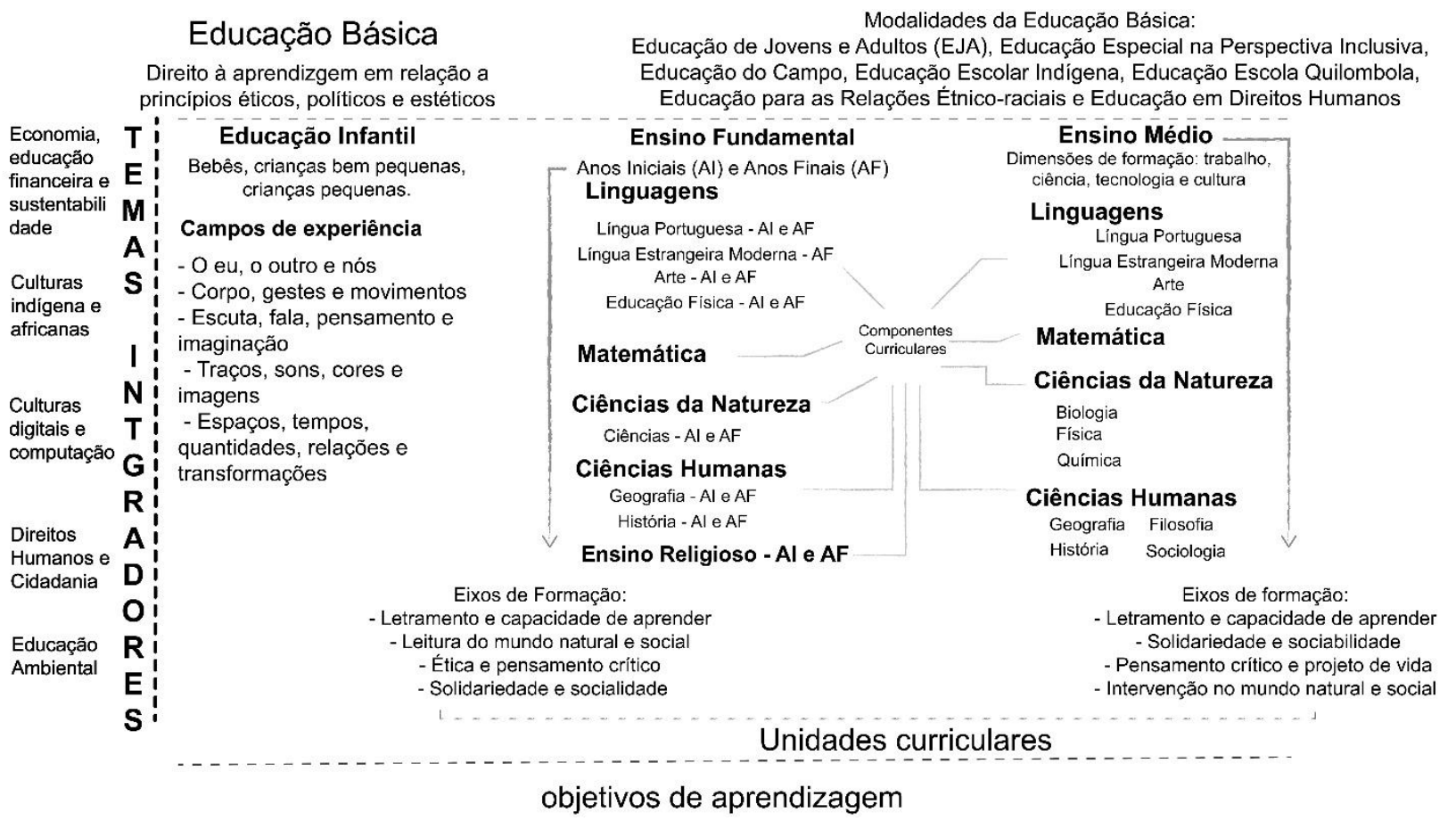

Fonte: Elaboração dos autores.

Essa segunda versão (Ver figura 3) está completa e já indica mudanças no Ensino Médio. O CONSED e o Movimento pela Base e Todos pela Educação já pressionavam o MEC e o corpo de assessores responsáveis pela articulação entre as equipes de especialistas a deixarem o Ensino Médio mais flexível (ver Quadro 2). Esperavam que um projeto de lei (2013) que tramitava no Congresso e propunha a reforma do Ensino Médio, enxugando seus componentes curriculares obrigatórios e direcionando-o para a profissionalização, fosse aprovado em breve ${ }^{5}$.

Quadro 2 - A elaboração da bncc em quatro documentOS - 2014, 2015, 2016 e 2018.

\begin{tabular}{|c|c|c|c|c|}
\hline $\begin{array}{l}\text { Princípios e formas de } \\
\text { organização da BNCC }\end{array}$ & $\begin{array}{l}\text { Documento (2013) } \\
2014\end{array}$ & Documento 2015 & $\begin{array}{l}\text { Documento } \\
2016\end{array}$ & $\begin{array}{c}\text { Documento (2017) } \\
2018\end{array}$ \\
\hline Legislação da Educação & $\begin{array}{l}\text { CF de } 1988 \\
\text { LDBEN de } 1996 \\
\text { DCNEB de } 2010 \\
\text { DCNEM de } 2012 \\
\text { Lei n. } 13.005 \text { de } 2014\end{array}$ & $\begin{array}{l}\text { CF de } 1988 \\
\text { LDBEN de } 1996 \\
\text { DCNEB de } 2010 \\
\text { DCNEM de } 2012 \\
\text { Lei n. } 13.005 \text { de } \\
2014\end{array}$ & $\begin{array}{l}\text { CF de } 1988 \\
\text { LDBEN de } 1996 \\
\text { DCNEB de } 2010 \\
\text { DCNEM de } 2012 \\
\text { Lei n. } 13.005 \text { de } \\
2014\end{array}$ & $\begin{array}{l}\text { CF de } 1988 \\
\text { LDBEN de } 1996 \\
\text { DCNEB de } 2013 \\
\text { Lei n. } 13.005 \text { de } 2014 \\
\text { Lei n.13 } 415 \text { de } 2017 \\
\text { (Novo EM-muda a } \\
\text { LDB) } \\
\text { DCNEM de } 2018\end{array}$ \\
\hline $\begin{array}{l}\begin{array}{l}\text { Função da } \\
\text { grade }\end{array} \\
\text { (currículo) } \\
\text { orientação geral. é }\end{array}$ & orien & $\begin{array}{l}\text { orientação geral, } \\
\text { mas com detalhes } \\
\text { de percursos }\end{array}$ & $\begin{array}{l}\text { orientação geral, } \\
\text { mas com } \\
\text { detalhes de } \\
\text { percursos, } \\
\text { menos para o } \\
\text { Ensino Médio } \\
\end{array}$ & orientação geral \\
\hline Princípios de seleção e & Direitos & Direitos e objetivos & Direitos & Habilidades \\
\hline
\end{tabular}

5 Referimo-nos ao Projeto de Lei n. 6840/2013, "Altera a Lei n 9.394, de 20 de dezembro de 1996, que estabelece as diretrizes e bases da educação nacional, para instituir a jornada em tempo integral no ensino médio, dispor sobre a organização dos currículos do ensino médio em áreas do conhecimento e dá outras providências" que tramitava desde $27 / 11 / 2013$. 


\begin{tabular}{|c|c|c|c|c|}
\hline $\begin{array}{l}\text { ordenamento das áreas, } \\
\text { ciências, disciplinas } \\
\text { escolares. }\end{array}$ & $\begin{array}{l}\text { aprendizagem e } \\
\text { desenvolvimento } \\
\text { (14 direitos) }\end{array}$ & $\begin{array}{l}\text { de aprendizagem } \\
\text { por etapa e séries. } \\
\text { EM -3 séries }\end{array}$ & $\begin{array}{l}\text { objetivos de } \\
\text { aprendizagem } \\
\text { EM - } 3 \text { unidades }\end{array}$ & $\begin{array}{l}\text { competências por } \\
\text { áreas. EM por áreas } \\
\text { na parte de carga } \\
\text { horária comum, os } \\
\text { itinerários e suas } \\
\text { cargas horárias } \\
\text { serão definidos nos } \\
\text { Estados. }\end{array}$ \\
\hline $\begin{array}{l}\text { A seleção e a definição } \\
\text { das áreas, dos } \\
\text { componentes } \\
\text { curriculares/disciplinas. }\end{array}$ & $\begin{array}{l}\text { Área de Linguagens } \\
\text { Área de Matemática } \\
\text { Área de Ciências } \\
\text { Humanas Área de } \\
\text { Ciências } \\
\text { Natureza }\end{array}$ & $\begin{array}{l}\text { Área de } \\
\text { Linguagens; Área } \\
\text { de Matemática; } \\
\text { Área de Ciências da } \\
\text { Natureza; Área de } \\
\text { Ciências Humanas }\end{array}$ & $\begin{array}{l}\text { Árear de } \\
\text { Linguagens; Área } \\
\text { de Matemática } \\
\text { Área de Área de } \\
\text { Ciências da } \\
\text { Natureza; Área } \\
\text { de Ciências } \\
\text { Humanas }\end{array}$ & $\begin{array}{l}\text { Área Linguagens e } \\
\text { suas tecnologias; } \\
\text { Área de Matemática } \\
\text { e suas Tecnologias } \\
\text { Área de Ciências da } \\
\text { natureza e suas } \\
\text { tecnologias, Área de } \\
\text { Ciências Humanas e } \\
\text { Sociais Aplicadas. }\end{array}$ \\
\hline $\begin{array}{l}\text { Agentes, Agências, } \\
\text { setores da sociedade } \\
\text { civil e do Estado que } \\
\text { participam. }\end{array}$ & $\begin{array}{l}\text { MEC, CNE, CONSED, } \\
\text { UNDIME, SEDUCS, } \\
\text { SEMEDS, IES, } \\
\text { ASSOCIAÇÕES } \\
\text { CIENTÍ́FICAS. UFPR } \\
\text { (Observatório do } \\
\text { Ensino Médio) }\end{array}$ & $\begin{array}{l}\text { MEC, CNE, } \\
\text { CONSED, UNDIME, } \\
\text { SEDUCS, SEMEDS, } \\
\text { IES, ASSOCIAÇÕES } \\
\text { CIENTÍFICAS } \\
\text { MOVIMENTOS } \\
\text { TODOS PELA } \\
\text { EDUCAÇÃO, } \\
\text { MOVIMENTO PELA } \\
\text { BASE, FUNDAÇÃO } \\
\text { LEMANN, UFJF } \\
\text { (CAED), UFMG } \\
\text { (CEALE) }\end{array}$ & $\begin{array}{l}\text { MEC, CNE, } \\
\text { CONSED, } \\
\text { UNDIME, } \\
\text { SEDUCS, } \\
\text { SEMEDS, IES, } \\
\text { ASSOCIAÇÕES } \\
\text { CIENTÍFICAS, } \\
\text { MOVIMENTOS } \\
\text { TODOS PELA } \\
\text { EDUCAÇÃO, } \\
\text { MOVIMENTO } \\
\text { PELA BASE, } \\
\text { FUNDAÇÃO } \\
\text { LEMANN, UFJF } \\
\text { *(CAED), UFMG } \\
\text { *(CEALE) }\end{array}$ & $\begin{array}{l}\text { MEC, CNE, CONSED, } \\
\text { UNDIME, SEDUCS, } \\
\text { SEMEDS, IES, } \\
\text { MOVIMENTOS } \\
\text { TODOS PELA } \\
\text { EDUCAÇÃO, } \\
\text { MOVIMENTO PELA } \\
\text { BASE, FUNDAÇÃO } \\
\text { LEMANN, } \\
\text { *FUNDAÇÃO } \\
\text { VANZOLINI-SP }\end{array}$ \\
\hline $\begin{array}{l}\text { Métodos de elaboração } \\
\text { e espaços que decidem. }\end{array}$ & 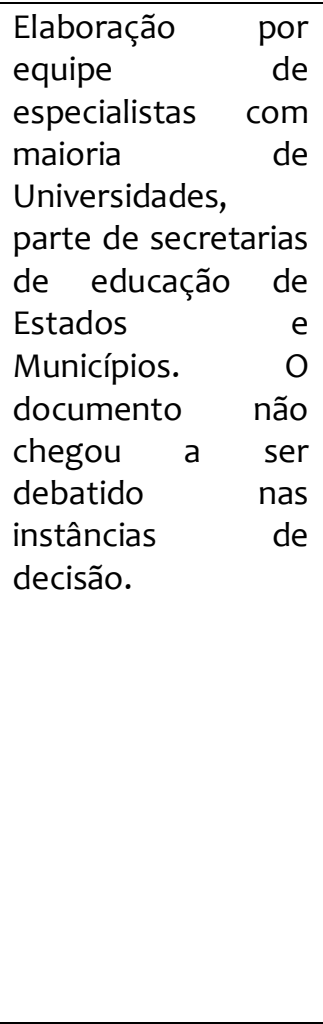 & 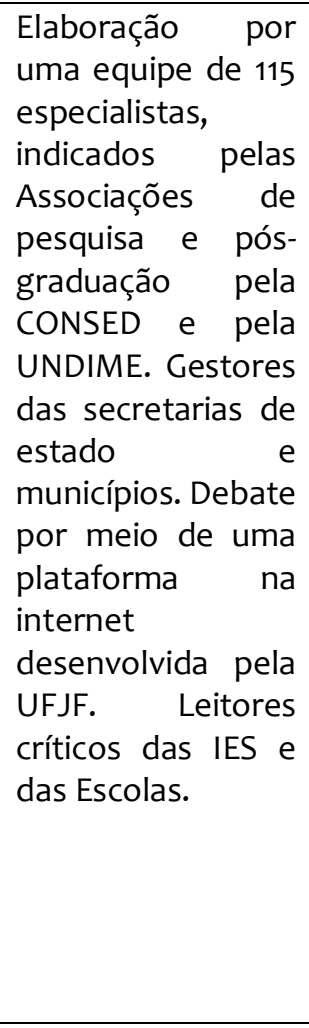 & 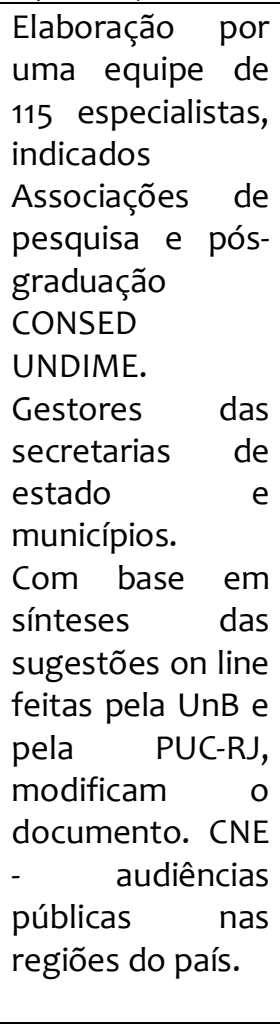 & 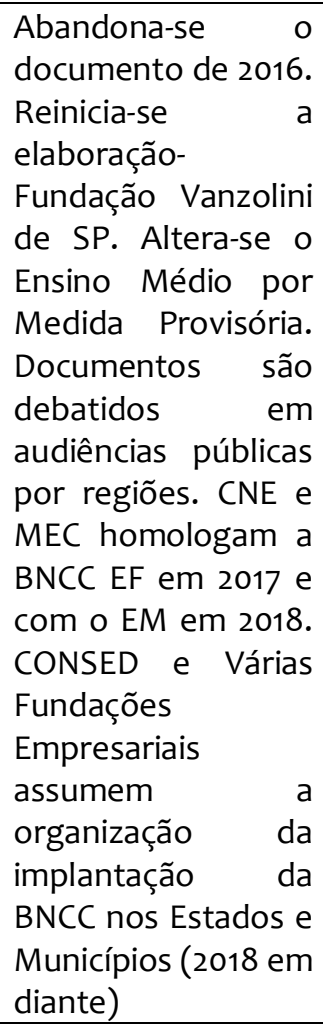 \\
\hline
\end{tabular}

Fuente: Elaborado pelos autores. 
*CAED - Centro de Políticas Públicas e Avaliação da Educação UFJF / CEALE O Centro de Alfabetização, Leitura e Escrita da UFMG/ Fundação Carlos Alberto Vanzolini - SP

Redefiniram-se os temas integradores, os objetivos de aprendizagem dos 13 componentes curriculares e o Ensino Médio não foi organizado por séries, mas por unidades sem sequência definida (ver figura 3 e Quadro 2)

Essa versão foi entregue para o Conselho Nacional de Educação em 3 de maio de 2016. Em 12 de maio, abriu-se o processo de impeachment da presidenta Dilma Rousseff. Note-se que essa fase final de elaboração da versão da BNCC foi marcada por profundas mudanças na conjuntura política e os atores que lutavam pela mudança no Ensino Médio viram uma janela de oportunidades para, na carona com o golpe jurídico e midiático que se iniciava, acelerarem as reformas na educação, especialmente, a do Ensino Médio.

Temos, então, o rompimento com o debate nacional nos moldes que vinha sendo conduzido (Silva et all, 2015). Rompe-se com o processo imediatamente anterior. Em 31 de agosto de 2016, Dilma Rousseff é afastada do cargo da presidência. Michel Temer assume e o MEC já tem uma Medida Provisória pronta para reformar o Ensino Médio, a MP nº 746 de 22 de setembro de 2016.

De maio a agosto de 2016 a nova equipe do MEC foi composta por antigos agentes experientes na gestão da educação e que retomam os projetos do Partido da Social Democracia (PSDB), que governou o Brasil de 1995 a 2002. Nomes como Maria Helena Guimarães, Guiomar Namo de Mello e Maria Inês Fini, entre outras, voltam à gestão do sistema nacional de educação e retomam os antigos projetos de configuração do Ensino Médio. Agilizam a feitura da BNCC, deixando o Ensino Médio para outro momento. Esse trabalho de reelaboração da proposta foi coordenado pela Fundação Alberto Vanzolini de São Paulo ${ }^{6}$, que concluiu a elaboração do documento em dezembro de 2017, da Educação Infantil até o Ensino Fundamental. Os estados, assessorados pelo CONSED e várias fundações econômicas e empresariais, elaboraram os seus Referenciais Curriculares desde o formato definido pela proposta homologada em 2017. Em 13 de fevereiro de 2017, o Governo promulga a Lei 13.415 que consolida a proposta da MP 746 de 2016 (Ver Quadro 2). Apresentaremos o documento final de 2018 que retomou o Ensino Médio, agora adequado às concepções da equipe à frente do MEC, pois é o mesmo de 2017, mas completo com a etapa do Ensino Médio (ver figura 4).

Esse é, então, o terceiro momento desse processo, que chamamos de a fase de finalização da BNCC sob a ótica das competências e habilidades e da reforma do Ensino Médio (2017-2018). Podemos sintetizar que, de agosto de 2016 a dezembro de 2018, outra proposta de BNCC foi elaborada, ela é completamente diferente das versões de 2015 e de 2016 que analisamos anteriormente (Ver figura 4).

6 Ver DIÁRIO OFICIAL DA UNIÃO, 23 de Março de 2017, nº 57. “EXTRATO DE CONTRATO N 17/2017 - UASG 150002 N Processo: 23000050898201638. DISPENSA N 7/2017. Contratante: MINISTERIO DA EDUCACÃO. CNPJ Contratado: 62145750000109: FUNDACAO CARLOS ALBERTO VANZOLINI Objeto: Prestação de serviços especializados para a gestão integrada dos processos necessários à consolidação, disponibilização, divulgação e discussão da $3^{\circ}$ versão da Base Nacional Comum Curricular (BNCC). Fundamento Legal: Lei 8.666/1993 e alterações. Vigência: 22/03/2017 a 22/03/2019. Valor Total: R\$18.923.297,00. Fonte: 112000000 - 2017NE800324. Data de Assinatura: 22/03/2017. Este documento pode ser verificado no endereço eletrônico http://www.in.gov.br/autenticidade.html, pelo código $00032017032300023 . "$ 
Figura 4 - A Proposta de BNCC de 2018 (BRASIL, 2018)

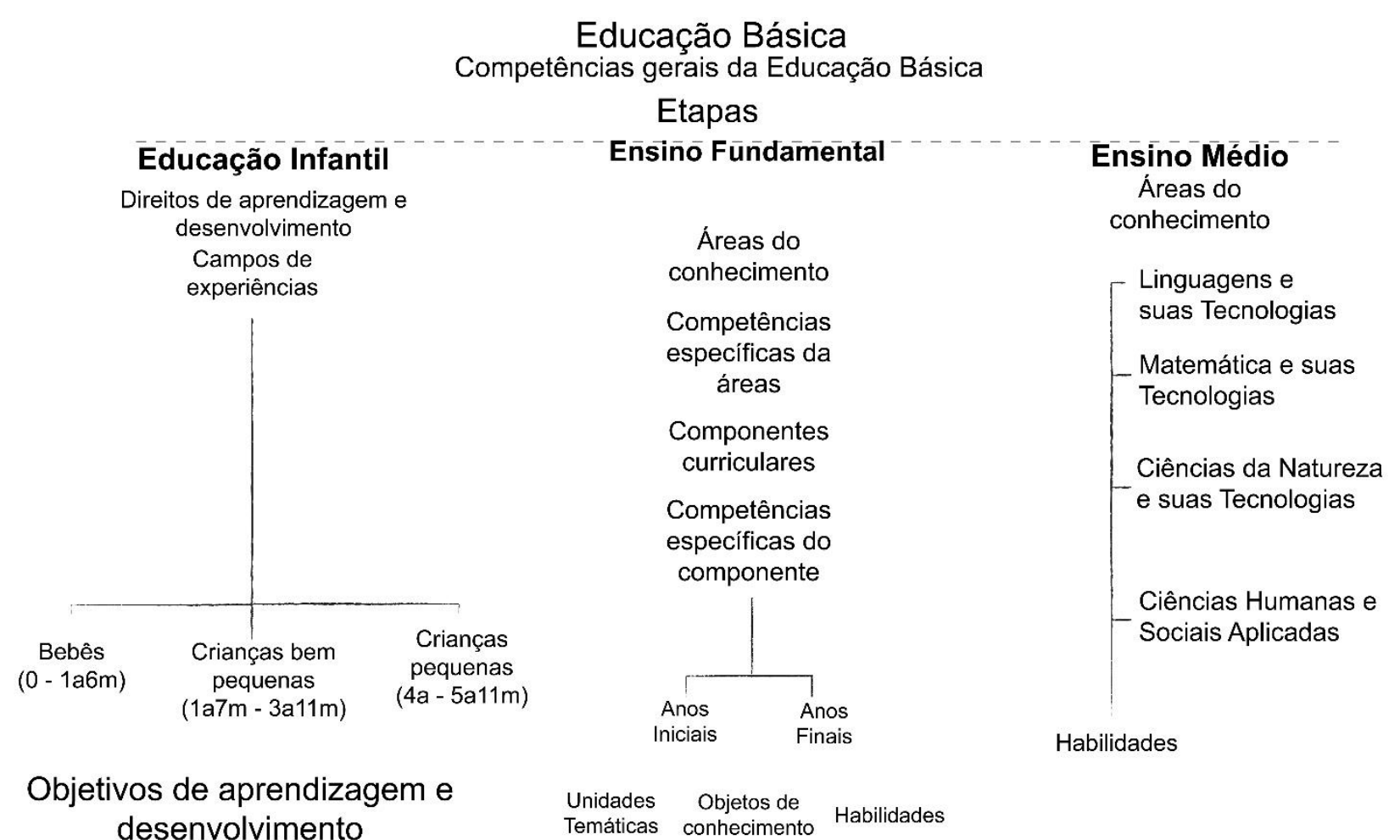

Fonte: Adaptada pelos autores desde o documento BRASIL, 2018, páginas 24, 27 e 32.

É importante ressaltar que, embora nesse documento final (2018) conste a história recente de elaboração e, ao final, listem todos os nomes de especialistas que participaram das versões de 2015 e 2016, de fato, não houve continuidade dos trabalhos e da participação desses agentes. Houve, como dissemos, um rompimento com o processo de integração do Ensino Médio como direito e obrigação do Estado (SILVA, 2020) e com os métodos de elaboração das propostas curriculares desde os anos de 1990 (SILVA et al, 2015). Dessa forma, admite-se que é um processo de seis anos (2013 a 2018) de formulação de propostas para uma BNCC, mas com rupturas (BURGOS, 2017; AZEVEDO, 2018).

Podemos sintetizar que ocorreram rupturas leves e severas nos princípios de organização da BNCC no que se refere à seleção e definição das áreas e dos componentes curriculares. Do documento de 2014 para o de 2016, não houve rupturas nos aspectos da legislação, mas uma ruptura em termos da função da base que no documento de 2016 passou a orientar detalhadamente sobre os objetivos de cada etapa, cada série para cada componente curricular, assumindo um formato próximo das matrizes de referências do SAEB e ENEM. O documento de 2016, também, já acena para mudanças no Ensino Médio, organizando os objetivos de aprendizagem por unidades.

Observamos rupturas mais severas entre os documentos de 2016 e o de 2018. Começando pela legislação, com a Lei n 13.415 de 2017 até chegar nas Diretrizes Curriculares Nacionais do Ensino Médio de 2018. Os princípios de seleção e de ordenamento das áreas retomam a pedagogia das competências e habilidades como direcionadoras das áreas e dos componentes curriculares, que mais uma vez usam como complemento nos títulos "e suas tecnologias", lembrando dos Parâmetros Curriculares Nacionais (PCN) de 1998. Ainda, em relação aos métodos de laboração e aos agentes e agências, a ruptura também é radical, pois delega-se a uma Fundação privada (Fundação Vanzolini) o trabalho de finalização do documento, abandonando o trabalho feito nos dois anos anteriores. Na implementação da BNCC de 2017 e 2018, o CONSED ganha centralidade em relação ao MEC e organiza a elaboração dos Referenciais Curriculares dos Estados junto com Instituto Unibanco, Itaú BBA, Oi Futuro, Instituto Natura, Movimento 
ISSN $1983-1579$

Doi: 10.22478/ufpb.1983-1579.2020v13n1.51545

http://periodicos.ufpb.br/ojs2/index.php

pela Base, Inspirare, Instituto Sonho Grande, Fundação Telefônica e Instituto Reúna. ${ }^{7}$

Percebe-se nesse processo uma forma de governança, em que essas agências do setor privado e financeiro monopolizam a forma e o conteúdo (MICHETTI, 2020), diminuindo as chances de interferência por meio da participação dos professores da educação básica e do ensino superior da rede pública, que são convocados na fase final do processo para opinar via plataformas na internet, com pouco espaço para o debate em grupo de forma mais intensa e presencial.

O que os estudos de Macedo (2014), Lopes (2017) e as críticas da ANPEd demonstravam como o grande risco de se lançar na aventura de elaborar uma BNCC para o país, ou seja, homogeneizar e centralizar os currículos segundo os princípios do mercado, aconteceu. O que Bernstein (1996, 2000, 2003) apontava como tendência nos currículos da Europa, que no final do século XX, estavam cada vez mais controlados pelo campo da produção e pelo aperfeiçoamento da divisão do trabalho no campo de controle simbólico, também se mostrou forte no Brasil após 2016. Uma diminuição da autonomia entre o campo da produção (ou do mercado) e do campo da educação. Assim, o campo da recontextualização pedagógica oficial e da reprodução nas escolas, também viram diminuídas suas autonomias em relação ao controle do Estado e do mercado.

\section{OS DISCURSOS PEDAGÓGICOS E A SOCIOLOGIA NAS QUATRO PROPOSTAS DE BNCC}

Segundo Bernstein (1996), discurso pedagógico é construído na interação do campo do controle da produção e do campo do controle simbólico. Nas décadas finais do século XX, o campo do controle simbólico tornou-se mais complexo em função da diversificação e fragmentação da divisão do trabalho de controle simbólico ${ }^{8}$. Nesse sentido, o autor estudou os princípios de ordenamento intrínsecos à produção, reprodução e mudança do discurso pedagógico, preenchendo uma lacuna na sociologia da educação quanto às atividades centrais dentro das escolas, ou seja, a transmissão e aquisição do conhecimento. Mas para dar esse passo teórico e metodológico foi preciso considerar mais do que as vozes presentes no discurso pedagógico e na sua reprodução. Bernstein (1996, p.229-230) indica que estudar os princípios de ordenamento e estruturação desse discurso articulando os campos de produção, recontextualização e reprodução é o caminho teórico e metodológico possível.

Bernstein $(1996,2000,2003)$ demonstrava sentidos que se insinuavam nos princípios de ordenamento do discurso pedagógico nas últimas décadas do século $\mathrm{XX}$, arriscando como forte probabilidade o enfraquecimento dos currículos de coleção, ou seja, organizados em torno das disciplinas. Currículos baseados em princípios de interdisciplinaridade e suas variações em torno de generalidades ganhariam força por meio de princípios ordenadores oriundos dos ambientes de gestão do campo econômico e do campo de controle simbólico (BERSNTEIN, 2000). Além disso, no artigo "A Pedagogização do Conhecimento", Bernstein (2003) elabora vários modelos e modos de currículos desenvolvidos em sociedades europeias, mostrando outra probabilidade para as primeiras décadas do século XXI: os modos genéricos de currículo sendo disputados e capturados pelas religiões e fundamentalismos. Diante do esvaziamento dos conteúdos das áreas científicas e das antigas disciplinas, os currículos também sofreriam a pressão frenética de definições identitárias fragmentadas, religiosas e fundamentalistas. Entretanto, tudo isso seria ordenado pelos princípios do campo econômico e da gerência do campo de controle simbólico. A diminuição da autonomia entre o campo de produção, campo de controle simbólico

7 CONSED, 2019, no site http://www.consed.org.br/consed/gt-ensino-medio, acessado em 10 março de 2020.

8 Basil Bernstein (1924-2000) apresentou, em 1988 em uma conferência em Santiago -Chile, uma hipótese de trabalho que pensava "[...] que quanto mais abstratos os princípios das forças de produção, mais simples seria a divisão social do trabalho, mas mais complexa a divisão social do trabalho de controle simbólico." (BERNSTEIN, 1996, p.187). Essas reflexões estão publicadas na Segunda parte (Sobre o Discurso Pedagógico) do livro "A Estruturação do Discurso Pedagógico: classe, códigos e controle”, traduzido da edição inglesa (volume IV) por Tomaz Tadeu da Silva e Luís Fernando Gonçalves Pereira e publicado na Editora Vozes em 1996. Não teremos espaço neste artigo para desenvolver detalhadamente o pensamento desse autor, por isso indicamos com mais dados a fonte dessas definições acerca do Discurso Pedagógico.

Rev. Espaço do Currículo (online), João Pessoa, v.13, n.2, p. 262-284, maio/agos. 2020. 
e campo da educação produziria outras gramáticas internas ao discurso pedagógico, mais próximas dos interesses do mercado e do campo da produção.

É o que podemos observar no processo de elaboração desses quatro documentos da BNCC no Brasil. Em quatro anos, vimos lutas de várias décadas atrás se acirrarem na sociedade civil. Tensões postas pela globalização, pelos novos padrões de regulação da produção econômica mundial, pela recomposição das classes sociais no Brasil, pelas lutas de reconhecimento da mulher, dos homossexuais, dos negros, dos índios, entre tantos movimentos sociais de reconhecimento, identitários e de classes, se intensificaram em fortes conflitos institucionais.

A sociologia participou de várias maneiras, como capital simbólico disputado e combatido por grupos conservadores, por meio de seus agentes e de suas agências de formação e de pesquisadores, de corporações de docentes, entre outras. Como os agentes e as agências dos outros componentes curriculares, ela também foi capturada pelos discursos pedagógicos, mas não sem resistências. Resistências nas escolas, nos textos em disputadas nos currículos e dentro do Estado. Entretanto, neste artigo trataremos de sua situação nos documentos oficiais que materializam os sentidos da BNCC no Brasil (Ver Quadro 3).

Quadro 3 - A sociologia na bncc em quatro documentos - 2014, 2015, 2016 e 2018

\begin{tabular}{|c|c|c|c|c|}
\hline $\begin{array}{l}\text { Princípios e formas de } \\
\text { organização da BNCC }\end{array}$ & $\begin{array}{c}\text { Documento (2013) } \\
2014 \\
\end{array}$ & Documento 2015 & $\begin{array}{c}\text { Documento } \\
2016 \\
\end{array}$ & $\begin{array}{c}\text { Documento (2017) } \\
2018 \\
\end{array}$ \\
\hline $\begin{array}{l}\text { Legislação } \\
\text { Educação }\end{array}$ & $\begin{array}{l}\text { LDBEN de } 1996 \\
\text { Lei } 11684 \text { de } 2008 \\
\text { (SOC e FIL) } \\
\text { DCNEB de } 2010 \\
\text { DCNEM de } 2012\end{array}$ & $\begin{array}{l}\text { LDBEN de } 1996 \\
\text { Lei } 11684 \text { de } 2008 \\
\text { (SOC e FIL) } \\
\text { DCNEB de } 2010 \\
\text { DCNEM de } 2012\end{array}$ & $\begin{array}{l}\text { LDBEN de } 1996 \\
\text { Lei } 11684 \text { de } 2008 \\
\text { (SOC e FIL) } \\
\text { DCNEB de } 2010 \\
\text { DCNEM de } 2012\end{array}$ & $\begin{array}{l}\text { LDBEN de } 1996 \\
\text { DCNEB de } 2013 \\
\text { Lei n.13 } 415 \text { de } 2017 \\
\text { (Novo EM-muda a LDB } \\
\text { e revoga a Lei } 11684 \text { de } \\
\text { 2008) } \\
\text { DCNEM de } 2018\end{array}$ \\
\hline $\begin{array}{l}\text { Organização das } \\
\text { etapas e níveis e o } \\
\text { lugar do Ensino Médio }\end{array}$ & 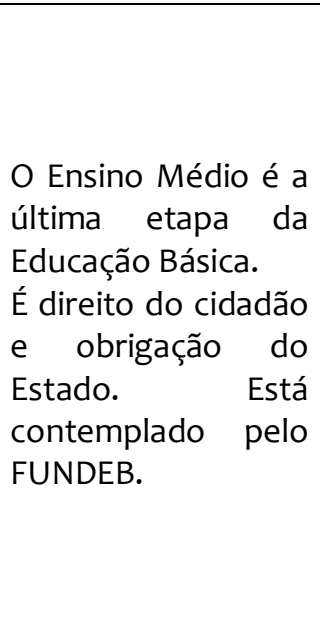 & $\begin{array}{l}\text { O Ensino Médio é a } \\
\text { última etapa da } \\
\text { Educação Básica. É } \\
\text { direito do cidadão e } \\
\text { obrigação do } \\
\text { Estado. } \\
\text { contemplado pelo } \\
\text { FUNDEB. }\end{array}$ & 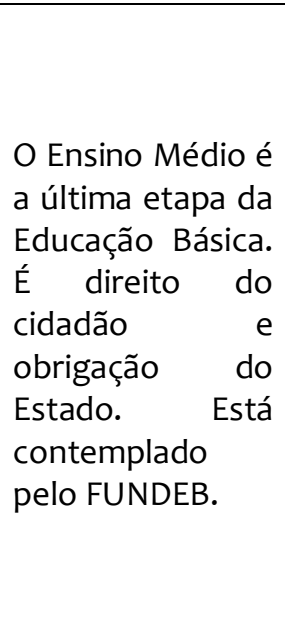 & $\begin{array}{l}\text { O Ensino Médio se } \\
\text { desprende da linha de } \\
\text { progressão de } \\
\text { formação das outras } \\
\text { etapas da Educação } \\
\text { Básica. É fragmentado } \\
\text { em itinerários } \\
\text { formativos, incluindo- } \\
\text { se um que é } \\
\text { profissionalizante. } \\
\text { Deixa de ser obrigação } \\
\text { do Estado e direito } \\
\text { básico do cidadão. } \\
\text { Extingue-se } \\
\text { FUNDEB. }\end{array}$ \\
\hline $\begin{array}{l}\text { Organização do Ensino } \\
\text { Médio }\end{array}$ & $\begin{array}{l}\text { Em três (EM } \\
\text { Regular) ou quatro } \\
\text { séries (Ensino } \\
\text { Médio } \\
\text { Profissionalizante } \\
\text { no modo } \\
\text { integrado), como } \\
\text { última etapa da } \\
\text { Educação Básica }\end{array}$ & $\begin{array}{l}\text { Em três (EM } \\
\text { Regular) ou quatro } \\
\text { séries (Ensino } \\
\text { Médio } \\
\text { Profissionalizante } \\
\text { no modo } \\
\text { integrado), como } \\
\text { última etapa da } \\
\text { Educação Básica }\end{array}$ & $\begin{array}{l}\text { Em três } \text { (EM } \\
\text { Regular) } \text { ou } \\
\text { quatro séries } \\
\text { (Ensinor Médio } \\
\text { Profissionalizante } \\
\text { no modo } \\
\text { integrado), como } \\
\text { última etapa da } \\
\text { Educação Básica }\end{array}$ & $\begin{array}{l}\text { Organizado tempo } \\
\text { integral, uma parte } \\
\text { comum concentrada } \\
\text { em língua Portuguesa } \\
\text { e Matemática Parte } \\
\text { dos itinerários } \\
\text { formativos divididos } \\
\text { em } 5 \text { possiblidades nas } \\
4 \text { áreas e mais uma - } \\
\text { Profissionalizante. }\end{array}$ \\
\hline $\begin{array}{l}\text { A seleção e a definição } \\
\text { das áreas, dos } \\
\text { componentes } \\
\text { curriculares/disciplinas. }\end{array}$ & $\begin{array}{l}\text { Área de Linguagens } \\
\text { (componentes - } \\
\text { Língua Portuguesa, } \\
\text { Língua Materna } \\
\text { (indígena), Língua }\end{array}$ & $\begin{array}{l}\text { Área de Linguagens } \\
\text { (componentes - } \\
\text { Língua Portuguesa, } \\
\text { Língua Estrangeira, } \\
\text { Arte e Educação }\end{array}$ & $\begin{array}{l}\text { Área de } \\
\text { Linguagens } \\
\text { (componentes - } \\
\text { Língua } \\
\text { Portuguesa, }\end{array}$ & $\begin{array}{l}\text { Área Linguagens e } \\
\text { suas tecnologias; Área } \\
\text { de Matemática e suas } \\
\text { Tecnologias; Área de } \\
\text { Ciências da natureza e }\end{array}$ \\
\hline
\end{tabular}




\begin{tabular}{|c|c|c|c|c|}
\hline & $\begin{array}{l}\text { Estrangeira, Arte e } \\
\text { Educação Física); } \\
\text { Área de Matemática } \\
\text { (Matemática); Área } \\
\text { de Ciências } \\
\text { Humanas } \\
\text { (Geografia, História, } \\
\text { Ensino Religioso, } \\
\text { Filosofia e } \\
\text { Sociologia); Área de } \\
\text { Ciências da } \\
\text { Natureza } \\
\text { componentes- } \\
\text { Ciências } \\
\text { Fundam), Biologia, } \\
\text { Química e Física) }\end{array}$ & $\begin{array}{l}\text { Física); Área de } \\
\text { Matemática } \\
\text { (Matemática); Área } \\
\text { de Área de Ciências } \\
\text { da Natureza } \\
\text { (componentes- } \\
\text { Ciências no Ens } \\
\text { Fundam., Biologia, } \\
\text { Química e Física); } \\
\text { Ciências Humanas } \\
\text { (Geografia, } \\
\text { História, Ensino } \\
\text { Religioso, Filosofia } \\
\text { e Sociologia); }\end{array}$ & $\begin{array}{l}\text { Língua } \\
\text { Estrangeira, Arte } \\
\text { e Educação } \\
\text { Física); Área de } \\
\text { Matemática } \\
\text { (Matemática); } \\
\text { Área de Área de } \\
\text { Ciências da } \\
\text { Natureza } \\
\text { (componentes- } \\
\text { Ciências (Ens } \\
\text { Fundam), } \\
\text { Biologia, Química } \\
\text { e Física); } \\
\text { Ciências } \\
\text { Humanas } \\
\text { (Geografia, } \\
\text { História, Ensino } \\
\text { Religioso, } \\
\text { Filosofia } \\
\text { Sociologia); }\end{array}$ & $\begin{array}{l}\text { suas tecnologias, Área } \\
\text { de Ciências Humanas e } \\
\text { Sociais Aplicadas. }\end{array}$ \\
\hline A Sociologia & $\begin{array}{l}\text { Componente } \\
\text { curricular } \\
\text { obrigatório em } \\
\text { todas as séries. }\end{array}$ & $\begin{array}{l}\text { Componente } \\
\text { curricular } \\
\text { obrigatório em } \\
\text { todas as séries. }\end{array}$ & $\begin{array}{l}\text { Componente } \\
\text { curricular } \\
\text { obrigatório em } \\
\text { todas as séries. }\end{array}$ & $\begin{array}{l}\text { Compõe a Área de } \\
\text { Ciências Humanas e } \\
\text { Sociais Aplicadas, na } \\
\text { parte básica e no } \\
\text { itinerário formativo. }\end{array}$ \\
\hline $\begin{array}{l}\text { Conteúdos da } \\
\text { Sociologia e das } \\
\text { Ciências Sociais }\end{array}$ & $\begin{array}{l}\text { Dissolvidos na Área } \\
\text { de Ciências } \\
\text { Humanas, com } \\
\text { indicação de quais } \\
\text { Direitos de } \\
\text { Aprendizagem } \\
\text { poderá contribuir. }\end{array}$ & $\begin{array}{l}\text { Definidos em cada } \\
\text { série, tendo como } \\
\text { eixos conteúdos } \\
\text { mais próximos da } \\
\text { Sociologia na } \\
\text { Primeira série; da } \\
\text { Antropologia na } \\
\text { Segunda e da } \\
\text { Política na terceira } \\
\text { série. }\end{array}$ & $\begin{array}{l}\text { Definidos em } \\
\text { unidades, tendo } \\
\text { como eixo a } \\
\text { Pesquisa e para } \\
\text { as unidades: } \\
\text { desigualdade } \\
\text { social (1), } \\
\text { diversidade (2) e } \\
\text { Estado de direito } \\
\text { (3). }\end{array}$ & $\begin{array}{lr}\text { Os conteúdos } & \text { do } \\
\text { componente } & \text { são } \\
\text { diluídos } & \text { nas } \\
\text { competências da área } \\
\text { de Ciências Humanas e } \\
\text { Sociais Aplicadas. Para } \\
\text { cada uma dessas } 6 \\
\text { competências foram } \\
\text { elaboradas de } 5 \text { a } 6 \\
\text { habilidades. }\end{array}$ \\
\hline
\end{tabular}

Fuente: Elaborado pelos autores.

A Sociologia seguiu sendo componente curricular nas quatro propostas de BNCC, contudo, com lugares e papéis diferentes condicionados pelos princípios de ordenamento e pela gramática interna dos discursos pedagógicos formatados em cada documento (Ver figuras 1, 2, 3 e 4; ver Quadros 2 e 3).

Observamos que o discurso pedagógico ainda está codificado pelos persistentes embates dos princípios que organizam os currículos em torno dos componentes curriculares (disciplinas) ou no modelo das competências e habilidades. Mas ao longo do tempo os textos foram sendo misturados, ressignificados, realocados sempre na tentativa de que alguns se fortalecessem e outros se enfraquecessem, sem exclui-los, mas formatando de maneira que uma hierarquia pudesse esboçar-se em termos do que valeria mesmo nos currículos. Isso fica evidente no esforço que os agentes elaboradores do documento de 2014 fizeram para distanciá-lo das matrizes de referências do SAEB e ENEM ou do sistema de avaliação em larga escala, mas não conseguiram distanciar-se dos PCN de 1998 no que se refere à organização por áreas. Entretanto, fazem uma conversão de princípios democráticos desde a legislação produzida pela Constituição Federal de 1988 e pela LDBEN de 1996, submetendo as áreas aos direitos dos estudantes, denominando de direitos à aprendizagem e ao desenvolvimento humano. Talvez sem uma intencionalidade clara, retomaram a noção de competências de forma mais coerente com os teóricos de origem, desde o campo da contextualização pedagógica, com Piaget, Chomsky, Garfinkle, operando com a ideia de igualdade de aquisição (BERNSTEIN, 2003, p77). 
Bernstein (2003) explica a lógica social do conceito de competência partindo de sua origem na epistemologia das Ciências Sociais, da Linguística e da Psicologia para entender os modos e modelos que foram se modificando no contexto de mudanças no capitalismo de transição.

A nossa hipótese é a de que é nessa origem conceitual que a noção de competências estava ligada à noção de democracia da aquisição ${ }^{9}$. E nos parece que o documento de 2014 pretendeu consagrar essa ideia de competência (implicitamente e inconscientemente) e, por isso, submeteu as áreas de conhecimentos e seus componentes aos quatorze macrodireitos à aprendizagem. Reconhecimento das práticas culturais; Valorização dos saberes; Linguagens; Preservação de Patrimônios; Formação e atuação política; Relação trabalho, ciência, tecnologia e cultura; Apropriação de conceitos e procedimentos; Historicidade; Reflexão crítica; Cuidado de si; Apropriação de Estratégias; Atuação consciente; Desenvolvimento de interesses e motivações; Compreensão da centralidade do trabalho (BRASIL, 2014, pp.47-50). O documento de 2018 retomou a noção de competência pela chave do liberalismo e do modelo de gestão do campo de controle simbólico. Assim, a ênfase recaiu na elaboração de listas de competências e habilidades para cada etapa da educação, para cada área, e sem detalhar isso em torno dos componentes curriculares. Esses deverão demonstrar como contribuirão para desenvolver as competências e as habilidades. Podemos dizer que os documentos de 2015 e 2016 ficaram entre a noção de competências na lógica social original da democracia de aquisição e na lógica liberal de gestão das identidades prospectivas na chave do mercado, como elaborava Bernstein em seu artigo de 1996, mas traduzido no Brasil em 2003 (BERNSTEIN, 2003).

Podemos observar melhor a disciplina sociologia e como os elaboradores adaptaram-na ao discurso pedagógico nos documentos de 2015 e 2016, nos quais ainda atuava com força a noção de gramática de conteúdos e de currículo de coleção. Ao delegar para as equipes de especialistas oriundos de associações específicas de cada componente curricular para elaborar as propostas de objetivos de aprendizagem, o MEC permitiu que a disputa narcísica e/ou corporativa de cada disciplina atuasse na definição dos dois documentos. Isso foi contido no documento de 2014 e no documento de 2018.

O que marca como a sociologia integrará cada proposta é que em 2015 e 2016 ela era obrigatória em todas as séries do Ensino Médio. E o Ensino Médio era a última etapa da Educação Básica com treze componentes curriculares quando no Ensino Regular e mais dez componentes quando no Ensino Médio Integrado ao Profissionalizante de quatro anos de duração. A Língua Portuguesa e a Matemática eram ensinadas em todas as séries do Ensino Médio por tradição, haja vista que não havia nenhuma lei complementar à LDBEN de 1996 para fazer cumprir essa medida. No caso da Filosofia e da Sociologia, havia a lei n. 11.684 de 2008 (Ver Quadro 2). Diante disso, a equipe de especialistas do componente de Sociologia ${ }^{10}$ elaborou uma divisão de objetivos de aprendizagem baseada em conteúdos das ciências sociais retomando as propostas de mais de quinze estados da federação além das formulações das Orientações Curriculares Nacionais para o ensino Médio de Sociologia- as OCNEM (BRASIL, 2006).

No documento de 2015, organizaram por eixos : "Primeiro ano/EM - Iniciação à perspectiva sociológica- a relação entre o eu e o nós; Segundo ano /EM - Processos de Formação de Identidades políticas e culturais; Terceiro ano/EM - Compreensão das formações políticas, da democracia e da cidadania e compreensão sociológica do trabalho" (BRASIL, 2015, pp. 298-300). Foram vinte e oito objetivos de aprendizagem criados a partir de conteúdos e distribuídos nos três anos.

No documento de 2016, organizaram por unidades: “Unidade 1 - Da sensibilização inicial à

9 Para demonstrar as mudanças e conversões do conceito de competências nos termos de Bernstein precisaríamos de mais espaço. Pretendemos fazer esse aprofundamento em outro artigo que está em construção. Indicamos essa possiblidade como hipótese para poder explorar mais na continuidade da pesquisa. Entretanto, já apontamos um limite. O documento de 2014 não teve maiores consequências políticas no debate que se seguiu e não foi objeto de mais pesquisas e estudos.

10 Cumpre informar que um dos autores deste artigo, a autora Ileizi Luciana Fiorelli Silva, participou da equipe de especialistas do componente curricular de Sociologia, por indicação da Sociedade Brasileira de Sociologia, de setembro de 2015 a maio de 2016. Seguramente, há o esforço de distanciamento do processo, mas alguns ruídos do envolvimento poderão aparecer nas análises. 
perspectiva sociológica à reflexão sobre a desigualdade social; Unidade 2 - Da Introdução a Abordagem socioantropológica à reflexão sobre diversidade sociocultural; Unidade 3 - Da formação do indivíduo e do cidadão moderno ao estado democrático de direito no Brasil”( BRASIL, 2016, pp. 673-676). Elaboraramse doze objetivos de aprendizagem para cada unidade, totalizando trinta e seis objetivos.

O documento de 2018 ordena a organização do Ensino Médio das 1800 horas (do total de três mil horas do Ensino Médio em tempo integral). Com a reforma do Ensino Médio instituída pela Lei 13.415 de 2017 a carga horária anual passa de oitocentas para mil horas de aulas/ano. Sendo que dessas três mil horas ao longo dos três anos, os estudantes deverão cumprir mil e oitocentas horas com a BNCC e mil e duzentas horas nos itinerários formativos. A configuração do Ensino Médio será a partir de cinco itinerários formativos, Brasil, Lei 13415, 2017, grifos nossos:

Art. 36. O currículo do ensino médio será composto pela Base Nacional Comum Curricular e por itinerários formativos, que deverão ser organizados por meio da oferta de diferentes arranjos curriculares, conforme a relevância para o contexto local e a possibilidade dos sistemas de ensino, a saber: I - linguagens e suas tecnologias; II - matemática e suas tecnologias; III - ciências da natureza e suas tecnologias; IV - ciências humanas e sociais aplicadas; $\mathrm{V}$ - formação técnica e profissional.

Os conteúdos serão organizados por áreas de conhecimento e os componentes curriculares subordinados às competências e habilidades definidas pela BNCC, distribuídos em mil e oitocentas horas ou seiscentas horas anuais, Brasil, Lei n 13.415, 2017, grifos nossos:

Art. 35-A. A Base Nacional Comum Curricular definirá direitos e objetivos de aprendizagem do ensino médio, conforme diretrizes do Conselho Nacional de Educação, nas seguintes áreas do conhecimento: I - linguagens e suas tecnologias; II - matemática e suas tecnologias; III - ciências da natureza e suas tecnologias; IV - ciências humanas e sociais aplicadas. $\$ 10$ A parte diversificada dos currículos de que trata o caput do art. 26, definida em cada sistema de ensino, deverá estar harmonizada à Base Nacional Comum Curricular e ser articulada a partir do contexto histórico, econômico, social, ambiental e cultural. § 20 A Base Nacional Comum Curricular referente ao ensino médio incluirá obrigatoriamente estudos e práticas de educação física, arte, sociologia e filosofia. § 300 ensino da língua portuguesa e da matemática será obrigatório nos três anos do ensino médio, assegurada às comunidades indígenas, também, a utilização das respectivas línguas maternas. § 40 Os currículos do ensino médio incluirão, obrigatoriamente, o estudo da língua inglesa e poderão ofertar outras línguas estrangeiras, em caráter optativo, preferencialmente o espanhol, de acordo com a disponibilidade de oferta, locais e horários definidos pelos sistemas de ensino.

Como havíamos afirmado desde o início, a sociologia não foi excluída do novo ensino médio e da BNCC de 2018. Entretanto, ela muda de status. Ela não tem lugar e carga horária definidas. Ela aparece na lei como "Estudos e Práticas de Sociologia". Assim, a nova gramática interna do discurso pedagógico governante não destaca o currículo de coleção e as disciplinas especificas. A pouca autonomia do campo de recontextualização pedagógica em relação ao campo de produção e ao campo do controle simbólico diminui, também, a autonomia das áreas de conhecimento e de seus componentes curriculares. Os professores de sociologia ainda presentes nas escolas e nas redes de ensino terão que repensar as justificativas e os modos de inserir nos processos de escolarização. A BNCC de 2018, a proposta vencedora, neste processo marcado por golpes políticos de governo, rupturas no pacto democrático geral e em particular na educação, não diz como a sociologia será organizada nas escolas, mas, no que ela diz em termos de competências e habilidades, promove uma verdadeira sociologização da área de ciências humanas e sociais aplicadas. Observe-se as figuras 5 e 6 com exemplos de competências e de habilidades: 
Figura 5 - Competências Especificas de Ciências Humanas e Sociais Aplicadas para O Ensino Médio.

\section{COMPETÊNCIAS ESPECÍFICAS DE CIÊNCIAS HUMANAS E} SOCIAIS APLICADAS PARA O ENSINO MÉDIO

1. Analisar processos políticos, econômicos, sociais, ambientais e culturais nos âmbitos local, regional, nacional e mundial em diferentes tempos, a partir de procedimentos epistemológicos e científicos, de modo a compreender e posicionar-se criticamente com relação a esses processos e às possíveis relações entre eles.

2. Analisar a formação de territórios e fronteiras em diferentes tempos e espaços, mediante a compreensão dos processos sociais, políticos, econômicos e culturais geradores de conflito e negociação, desigualdade e igualdade, exclusão e inclusão e de situações que envolvam o exercício arbitrário do poder.

3. Contextualizar, analisar e avaliar criticamente as relações das sociedades com a natureza e seus impactos econômicos e socioambientais, com vistas à proposição de soluções que respeitem e promovam a consciência e a ética socioambiental e o consumo responsável em âmbito local, regional, nacional e global.

4. Analisar as relações de produção, capital e trabalho em diferentes territórios, contextos e culturas, discutindo o papel dessas relações na construção, consolidação e transformação das sociedades.

5. Reconhecer e combater as diversas formas de desigualdade e violência, adotando princípios éticos, democráticos, inclusivos e solidários, e respeitando os Direitos Humanos.

6. Participar, pessoal e coletivamente, do debate público de forma consciente e qualificada, respeitando diferentes posições, com vistas a possibilitar escolhas alinhadas ao exercício da cidadania e ao seu projeto de vida, com liberdade, autonomia, consciência crítica e responsabilidade.

Fuente: Cópia (print) BNCC de 2018 (BRASIL, 2018, P. 558) 
ISSN $1983-1579$

Doi: 10.22478/ufpb.1983-1579.2020v13n1.51545

http://periodicos.ufpb.br/ojs2/index.php

Figura 6 - Habilidades da Competência Específica 1.

\section{HABILIDADES}

(EM13CHS101) Analisar e comparar diferentes fontes e narrativas expressas em diversas linguagens, com vistas à compreensão e à crítica de ideias filosóficas e processos e eventos históricos, geográficos, políticos, econômicos, sociais, ambientais e culturais.

(EM13CHS102) Identificar, analisar e discutir as circunstâncias históricas, geográficas, políticas, econômicas, sociais, ambientais e culturais da emergência de matrizes conceituais hegemônicas (etnocentrismo, evolução, modernidade etc.), comparando-as a narrativas que contemplem outros agentes e discursos.

(EM13CHS103) Elaborar hipóteses, selecionar evidências e compor argumentos relativos a processos políticos, econômicos, sociais, ambientais, culturais e epistemológicos, com base na sistematização de dados e informações de natureza qualitativa e quantitativa (expressões artísticas, textos filosóficos e sociológicos, documentos históricos, gráficos, mapas, tabelas etc.).

(EM13CHS104) Analisar objetos da cultura material e imaterial como suporte de conhecimentos, valores, crenças e práticas que singularizam diferentes sociedades inseridas no tempo e no espaço.

(EM13CHS105) Identificar, contextualizar e criticar as tipologias evolutivas (como populações nômades e sedentárias, entre outras) e as oposições dicotômicas (cidade/ campo, cultura/natureza, civilizados/bárbaros, razão/sensibilidade, material/virtual etc.), explicitando as ambiguidades e a complexidade dos conceitos e dos sujeitos envolvidos em diferentes circunstâncias e processos.

(EM13CHS106) Utilizar as linguagens cartográfica, gráfica e iconográfica e de diferentes gêneros textuais e as tecnologias digitais de informação e comunicação de forma crítica, significativa, reflexiva e ética nas diversas práticas sociais (incluindo as escolares) para se comunicar, acessar e disseminar informações, produzir conhecimentos, resolver problemas e exercer protagonismo e autoria na vida pessoal e coletiva. Fuente: Cópia (print) da BNCC de 2018 (BRASIL, 2018, p.560)

Há conhecimentos e conteúdos das ciências sociais orientando as competências e habilidades, mas certamente não há a especialização clara entre os componentes curriculares que fazem parte dessa área. Essa tendência, que Bernstein (2003) já indicava nos seus estudos nos anos de 1970 em diante, consolidou-se no mundo inteiro, ou seja, o modelo genérico de currículo, Bernstein, 2003, p.94, grifos nossos:

Se as disciplinas singulares foram a forma modal da organização discursiva durante os 100 anos entre meados do século XIX e meados do século XX, é possível que as regiões se tornem a forma modal a partir do final do século XX. As identidades produzidas pelas novas regiões mais provavelmente se voltarão para os campos da prática e, assim, suas disputas tenderão a ser dependentes das necessidades desses campos. Aqui, as identidades são o que são e aquilo que se tornarão, como consequência da projeção daquele conhecimento como prática em algum contexto. E o futuro daquele contexto regulará a identidade. A volatilidade daquele contexto controlará a natureza da regionalização 
do conhecimento e, assim, a identidade projetada. Se os procedimentos da introjeção elaboram as identidades produzidas pelas disciplinas singulares, então os procedimentos da projeção elaboram as identidades produzidas pela nova regionalização do conhecimento.

Regiões, para Bernstein (2003), são campos tais como a Administração, a Medicina, a Pedagogia, a Informática, a Engenharia, as diversas áreas técnicas e tecnológicas, em que as diferentes disciplinas e seus conhecimentos são aplicados e dependentes desses contextos profissionais. Nas escolas de educação infantil, ensino fundamental e ensino médio, as regiões podem ser as áreas, quando juntamos disciplinas e a dissolvemos em uma área como Ciências Humanas, Ciências naturais, Estudos sociais, enfim, agrupamos conhecimentos aplicados a uma área de estudos.

No Brasil, o modo de agrupar as disciplinas em regiões tem sido organizar as competências, mas não necessariamente na lógica social de origem dessa noção, como tentaram os elaboradores do documento de 2014. A lógica social da noção de competências como gramática ativa do discurso pedagógico do documento da BNCC de 2018 é a do campo da produção ou do mercado como regulador e selecionador dos textos e códigos legítimos. A sociologia foi capturada por essa lógica da noção de competências, mas também como texto instituidor das habilidades pretendidas para a formação dos estudantes do Ensino Médio.

\section{CONSIDERAÇÕES FINAIS}

A título de síntese, podemos afirmar que as quatro propostas de BNCC analisadas revelam que os modelos de currículos direcionados pelo discursos pedagógicos produzidos pelos produtores de ordenamentos para o sistema de ensino brasileiro foram desenhados nas lutas pela autonomia entre os campos de produção e de controle simbólico em relação ao estado, ao campo de recontextualização pedagógica, portanto, pela diminuição da autonomia entre o campo da produção e o campo da educação. Nessas lutas a noção de competência como gramática interna da estruturação do discurso pedagógico foi ressignificada nas propostas de 2014, 2016 e 2018, sendo cada vez mais capturada pelos princípios do mercado, haja vista o crescimento do poder e da influência das fundações econômicas durante e ao final do processo.

A sociologia será moldada por essa gramática interna do discurso pedagógico, que também diminuiu a autonomia das disciplinas em relação aos princípios de ordenamento dos currículos. A tendência de enfraquecimento dos currículos de coleção apontada por Bernstein $(1996,2003)$ mostrou-se forte no Brasil do século XXI, que produziu uma BNCC que dissolve os conteúdos dos componentes curriculares em listas de competências e habilidades definidas em cada área.

Por outro lado, a ressignificação dos conteúdos das ciências sociais e da sociologia dentro da área de Ciências Humanas e Sociais Aplicadas indica uma sociologização das competências e habilidades, que deixam um caminho em aberto para ação de adesão e/ou resistência dos professores e das professoras de sociologia presentes nas escolas, durante o processo de implantação da BNCC nos estados, nos próximos anos.

Não poderíamos deixar de registrar que, no momento da conclusão deste artigo, estamos em quarentena no mundo inteiro por conta de um vírus letal, o COVID-19, que mata por problemas respiratórios agravados. O Brasil tem demorado para se organizar para minimizar os efeitos dessa pandemia, liderado por um Presidente da República com características antidemocráticas, Jair Messias Bolsonaro (sem Partido), que assumiu o cargo em 2019 e tem realizado reformas na educação, que apagam a ciência e ressaltam as religiões de matriz cristã, notadamente, as neopentecostais. A disputa pelo currículo ganhou novos sentidos, e, agora, enfrenta um fundamentalismo religioso e negacionista das conquistas e dos conhecimentos científicos. Mais uma vez, Bernstein acertou ao apontar como uma das consequências dos modelos de currículos genéricos e generalizantes, esvaziados de conteúdos e de disciplinas científicas. Na falta das identidades disciplinares, as culturais, elitistas e fundamentalistas (nacionalismos, populismos e religiões) prosperariam no século XXI (BERNSTEIN, 2003, pp. 104-108).

\section{REFERÊNCIAS}

AZEVEDO, Gustavo Cravo. A base nacional comum curricular atropelada pela reforma do ensino médio: 
ISSN $1983-1579$

Doi: 10.22478/ufpb.1983-1579.2020v13n1.51545

http://periodicos.ufpb.br/ojs2/index.php

uma entrevista com Marcelo Burgos. Revista Perspectiva Sociológica, n. ${ }^{2}$ 21, pp. 5-20, 2018. Disponível em: https://cp2.g12.br/ojs/index.php/PS/article/view/1738. Acessado em: 25 mar. 2020.

BERNSTEIN, Basil. A Estruturação do discurso pedagógico: classes, códigos e controle. Petrópolis: Vozes, 1996.

. A Pedagogização do conhecimento: estudos sobre recontextualização. Cadernos de Pesquisa, São Paulo, n. 120, p. 75-110, 2003. Disponível em: https://www.scielo.br/scielo.php?pid=S010015742003000300005\&script=sci_abstract\&tlng=pt. Acessado em: 03 mar. 2020.

. Pedagogy, Symbolic and Identity: Theory, research, critique. Lanham: Rowman \& Littlefield, 2000.

BRASIL. Ministério da Educação. Base Nacional Comum Curricular - $1^{a}$ versão. Brasília: MEC, 2015. Disponível em: http://basenacionalcomum.mec.gov.br/historico/. Acessado em: 10 abr. 2020.

. Base Nacional Comum Curricular - $2^{a}$ versão. Brasília: MEC, 2016. Disponível em: http://basenacionalcomum.mec.gov.br/historico/. Acessado em: 11 abr. 2020.

. Base Nacional Comum Curricular - $3^{\text {a }}$ versão. Ensino Médio. Brasília: MEC, 2018. Disponível em: http://basenacionalcomum.mec.gov.br/historico/. Acessado em: 20 abr. 2020.

. Base Nacional Comum Curricular - $3^{\text {a }}$ versão. Sem o Ensino Médio. Brasília: MEC, 2017. Disponível em: http://basenacionalcomum.mec.gov.br/historico/. Acessado em: 23 abr. 2020.

BRASIL. Ministério da Educação. Por uma política curricular para a educação básica: contribuição ao debate da base nacional comum a partir do direito à aprendizagem e ao desenvolvimento. Versão Preliminar. Brasília: MEC, 2014.

BURGOS, Marcelo Baumann. O processo de construção da proposta da sociologia para a base nacional curricular comum (2015). In: SILVA, Ileizi Fiorelli; GONÇALVES, Danyelle Nilin (Org.). A Sociologia na Educação Básica. São Paulo: Annablume, 2017. p. 107 - 128.

CORREIRA LIMA, Alexandre Jeronimo. Teorias e métodos em pesquisas sobre ensino de sociologia. Dissertação (Mestrado em Ciências Sociais) - Universidade Estadual de Londrina, Centro de Letras e Ciências Humanas, Programa de Pós-Graduação em Ciências Sociais. Londrina, 2012.

CORTINAZ, Tiago. A Construção da Base Nacional Comum Curricular (BNCC) para o Ensino Fundamental e sua relação com os conhecimentos escolares. Tese de Doutorado (Programa de Pós-graduação em Educação) - Universidade Federal do Rio Grande do Sul, Porto Alegre, 2019.

LOPES, Alice Casimiro. Por um currículo sem fundamentos. Linhas Críticas, v. 21, n. 45, p. 445-466, 2017. Disponível em: https://periodicos.unb.br/index.php/linhascriticas/article/view/4581. Acesso em 3 mar. 2020.

MACEDO, E. Base Nacional Curricular Comum: Novas formas de sociabilidade produzindo sentidos para educação. Revista e-Curriculum, v.12, n. 3, p.1530-1555, out./dez., 2014. Disponível em: https://revistas.pucsp.br/index.php/curriculum/article/view/21666. Acesso em: 10 abr. 2020.

MAINARDES, Jefferson; STREMEL, Silvana. A teoria de Basil Bernstein e algumas de suas contribuições para as pesquisas sobre políticas educacionais e curriculares. Revista Teias, v. 11, n. 22, mai./ago., 2010. Disponível em: https://www.e-publicacoes.uerj.br/index.php/revistateias/article/view/24114. Acesso em: 12 mar. 2020.

MICHETTI, Miqueli. Entre a legitimação e a crítica: as disputas acerca da Base Nacional Comum Curricular. Revista Brasileira de Ciências Sociais, São Paulo, v. 35, n. 102, 2020. Disponível em: https://www.scielo.br/scielo.php?pid=S0102-69092020000100507\&script=sci_arttext. Acesso em: 20 mar. 2020.

MORAIS, Ana Maria; NEVES, Isabel Pestana. A teoria de Basil Berstein: alguns aspectos fundamentais. Práxis Educativa, v. 2, n. 2, p. 115-130, jul./dez., 2007. Disponível em: 
https://www.revistas2.uepg.br/index.php/praxiseducativa/article/view/313. Acesso em: 5 mar. 2020.

SANTOS, Mário Bispo. Diretrizes curriculares estaduais para o ensino de sociologia: em busca do mapa comum. Percursos, Florianópolis, v. 13, n. 01, p. 40 - 59, jan. / jun, 2012. Disponível em: http://www.revistas.udesc.br/index.php/percursos/article/view/2439/2066. Acesso em: 20 abr. 2020.

SILVA, lleizi Luciana Fiorelli et al. A proposta da Base Nacional Comum Curricular e o debate entre 1988 e 2015. Ciências Sociais Unisinos, 2015, 51, 3:330-42. Disponível em: http://revistas.unisinos.br/index.php/ciencias_sociais/article/view/csu.2015.51.3.10. Acesso em: 09 mar. 2020.

SILVA, Ileizi Fiorelli. A sociologia no ensino médio: os desafios institucionais e epistemológicos para a consolidação da disciplina. Revista Cronos, v. 8, n. 2, 12 maio 2012. Disponível em: https://periodicos.ufrn.br/cronos/article/view/1844. Acesso em: 10 mar. 2020.

SILVA, Monica Ribeiro da. Ampliação da obrigatoriedade escolar no Brasil: o que aconteceu com o Ensino Médio?. Ensaio: aval.pol.públ.Educ., Rio de Janeiro , v. 28, n. 107, p. 274-291, 2020 . Disponível em: https://www.scielo.br/pdf/ensaio/v28n107/1809-4465-ensaio-S0104-40362019002701953.pdf. Acesso em: 7 mar. 2020.

SILVA, Tomaz Tadeu da. Documentos de Identidade: uma introdução às teorias do currículo. Belo Horizonte: Autêntica, 2005.

Recebido em: 30/03/2020

Alterações recebidas em: 20/04/2020

Aceito em: 20/04/2020

Publicado em: 20/04/2020 